\title{
Provenance and paleogeographic reconstruction of a mesoproterozoic intracratonic sag basin (Upper Espinhaço Basin, Brazil)
}

\author{
M.N. Santos ${ }^{\text {a,b,* }}$, F. Chemale Jr. ${ }^{\text {a }}$, I.A. Dussin ${ }^{\mathrm{c}}$, M.S. Martins ${ }^{\mathrm{d}}$, G. Queiroga ${ }^{\mathrm{d}}$, R.T.R. Pinto ${ }^{\mathrm{e}}$, \\ A.N. Santos ${ }^{\text {f }}$, R. Armstrong ${ }^{g}$ \\ a Programa de Pós-Graduação em Geologia, Instituto de Geociências, Universidade de Brasília, 70904-970, Brasília, DF, Brazil \\ b PETROBRAS/EEP-EXP, Avenida República do Chile, 330 - Centro, 20031-170, Rio de Janeiro, RJ, Brazil \\ ' Faculdade de Geologia, Universidade do Estado do Rio de Janeiro, 20550-013, Rio de Janeiro, RJ, Brazil \\ d DEGEO/EM/UFOP, Morro do Cruzeiro, 35400-000, Ouro Preto, MG, Brazil \\ e Departamento de Geologia, Universidade Federal do Espírito Santo, 29500-000, Alegre, ES, Brazil \\ ${ }^{\mathrm{f}}$ Instituto de Geociências, Universidade Federal do Rio Grande do Sul, 91501-970, Porto Alegre, RS, Brazil \\ ${ }^{g}$ RSES, ANU, Canberra, Australia
}

\section{A R T I C L E I N F O}

\section{Article history:}

Received 22 September 2014

Received in revised form 23 December 2014

Accepted 23 December 2014

Available online 30 December 2014

Editor: J. Knight

\section{Keywords:}

Stenian

Espinhaço basin

$\mathrm{U}-\mathrm{Pb}$ zircon geochronology

São Francisco craton

\begin{abstract}
A B S T R A C T
The Mesoproterozoic Conselheiro Mata Group is the uppermost sequence of the Proterozoic intracontinental Espinhaço basin that developed on the Congo-São Francisco Paleoplate. This sequence is represented by a marine shallow-water platform that experienced a sag phase followed by a rift phase in the Upper Espinhaço. We used combined sedimentological-stratigraphic descriptions of sections, whole-rock (WR) geochemistry and U-Pb detrital zircon dating to develop a regional paleogeographic evolution model of the sag phase. The succession corresponds to transgressive-regressive cycles in the following ascending order: 1 ) offshore to lower shoreface facies represented by quiescent periods and episodic sediment supply (Santa Rita Formation); 2) upper shoreface to foreshore and coastal desert facies with a reworking of the underlying units (Córrego dos Borges Formation); 3) lower shoreface with fallout of suspended fine sediments and a combination of unidirectional and oscillatory flows generated by storm waves (Córrego da Bandeira Formation); 4) tidal-influenced upper shoreface to foreshore facies with the migration of subaqueous dunes, wave swash in a beach environment and cycles of neap-spring tides (Córrego Pereira Formation); and 5) the resumption of lower-shoreface sedimentation and the subsequent development of a stromatolitic carbonate-siliciclastic platform (Rio Pardo Grande Formation). The geochemical data indicate that the studied units contain input from felsic rocks and sedimentary rocks. The basal marine to eolian sediments of the Galho do Miguel Formation are dominated by Rhyacian sources $(2.1 \mathrm{Ga})$. The basal and intermediate units of the Conselheiro Group contain Archean, Rhyacian, Statherian and Calymmian-Ectasian (1.6-1.33 Ga) zircon grains, whereas Orosirian (1.9-2.0 Ga) sources dominate in the upper strata of the group. The study of this Stenian (Mesoproterozoic) intracratonic sequence provides clues to understanding the history of sedimentation and the potential source areas on the São Francisco Craton and adjacent areas, which are very useful for comparison to Phanerozoic intracratonic basins and the reconstruction of Paleoproterozoic and Mesoproterozoic supercontinents.
\end{abstract}

(C) 2014 Elsevier B.V. All rights reserved.

\section{Introduction}

Intracratonic basins are located on stable continental lithosphere comprising several basin phases or megasequences with preserved continental to shallow-water marine deposits separated by regional unconformities (e.g., Sloss, 1963; Lindsay, 2002; Allen and Armitage, 2012). The study of Precambrian cratonic basins, which are similar to Phanerozoic basins, can provide important information on the paleogeography and distribution of continents and the evolution of supercontinents

\footnotetext{
* Corresponding author at: PETROBRAS/E\&P-EXP, Avenida República do Chile, 330 Centro, 20031-170, Rio de Janeiro, RJ, Brazil. Tel.: + 553891788699.

E-mail address: marcelodega@hotmail.com (M.N. Santos).
}

(e.g., Lindsay, 2002) and can elucidate the composition and paleodrainage dispersion of basement rocks. The spatial and temporal evolution of depositional systems in intracratonic rift and rift-sag basins depends on a complex relationship between sediment supply, eustatic variations, climate and tectonic processes at the time of deposition (Bosence, 1998; Bergner et al., 2009; Allen and Armitage, 2012). Hence, different models of tectonic evolution imply different models of the distribution and evolution of depositional systems (Prosser, 1993; Gawthorpe and Leeder, 2000), although the latter are a direct result of the particularities of each basin and data available for analysis (e.g., seismic data versus well logs or outcrop observations; Catuneanu et al., 2009). Nevertheless, there are many similarities among depositional systems in most rift basins, such as fluvial and alluvial fans that developed during a syn-rift 
stage (Prosser, 1993; Gawthorpe and Leeder, 2000) or marine depositional environments during a basinal sag phase (e.g., Porcupine Basin; Tate, 1993), similar to the conditions observed in the intracratonic Espinhaço Basin, eastern Brazil.

The southern Espinhaço Basin has been widely interpreted as an intracontinental rift-sag basin that developed on the Paleoproterozoic Congo-São Francisco Paleoplate (e.g., Martins-Neto, 1998; Alkmim and Martins-Neto, 2012; Chemale et al., 2012) and on the Neoproterozoic to Eopaleozoic deformed Araçuai Belt along the margin of the São Francisco Craton (Marshak and Alkmim, 1989; Chemale et al., 1993). According to Chemale et al. (2012), the Espinhaço Supergroup in Minas Gerais comprises metasedimentary units that record two distinct rift phases separated by a gap of $500 \mathrm{Ma}$ (i.e., a rift phase started at $1.7 \mathrm{Ga}$ and a rift-sag phase started at approximately $1.2 \mathrm{Ga}$ ), named the Lower and Upper Espinhaço Sequences. The sag phase of the Upper Sequence corresponds to the Conselheiro Group, which is characterized by a marine incursion over eolian sediments (Dupont, 1995; Martins-Neto, 2000).

This paper focuses on the evolution of the depositional systems and sediment provenance during the sag phase of the Conselheiro Mata Group by applying concepts of sequence stratigraphy and detrital zircon $\mathrm{U}-\mathrm{Pb}$ geochronology to propose a regional paleogeographic evolution model. The study of the marine sequence associated with the sag phase in the Espinhaço Basin enables a better understanding of the sedimentation history along the São Francisco Craton and how the successive transgression-regression events controlled the extent of the basin and basement exposed to subaerial processes, sediment supply and paleocurrent patterns.

\section{Geological setting}

The Espinhaço Basin forms part of a complex rift system that extends approximately north-south from Minas Gerais to Bahia in Brazil. The basin in the study area comprises the Serra do Cabral region, located in the São Francisco Craton, and the western portion of the southern Serra do Espinhaço in the Araçuaí Fold Belt (Pflug, 1968; Dussin and Dussin, 1995; Uhlein et al., 1998; Martins-Neto, 2000) (Fig. 1).

The São Francisco Craton is defined as one of the most stable parts of the South American Platform and was not involved in the Brasiliano Orogeny during the late Neoproterozoic (Alkmim, 2004). The transition from the eastern São Francisco Craton to the Araçuaí Fold Belt is marked by the deformation of the basin and the appearance of portions of basement reworked during the Brasiliano Orogeny with a clear vergence toward the craton (Marshak and Alkmim, 1989; Chemale et al., 1993; Dussin and Dussin, 1995; Uhlein et al., 1998). From a lithostratigraphic point of view, the Archean basement comprises the Basal Complex and the Rio Paraúna Supergroup. The Basal Complex includes granites (dated by U-Pb in zircon to $2938 \pm 14 \mathrm{Ma}$; Machado et al., 1989), gneisses, amphibolites and migmatites (Schöll and Fogaça, 1979), whereas the Rio Paraúna Supergroup is composed mainly of schists and metavolcanic rocks (with zircon grains from a rhyolite dated to $2971 \pm 16$ Ma; Machado et al., 1989).

Recent geochronological data and detailed sedimentological-stratigraphic studies applying sequence stratigraphy have revealed three second-order depositional sequences (sensu Krapez, 1996) for the Espinhaço Supergroup deposits - the Lower, Middle and Upper Espinhaço (Chemale et al., 2012). The record of the Middle Espinhaço
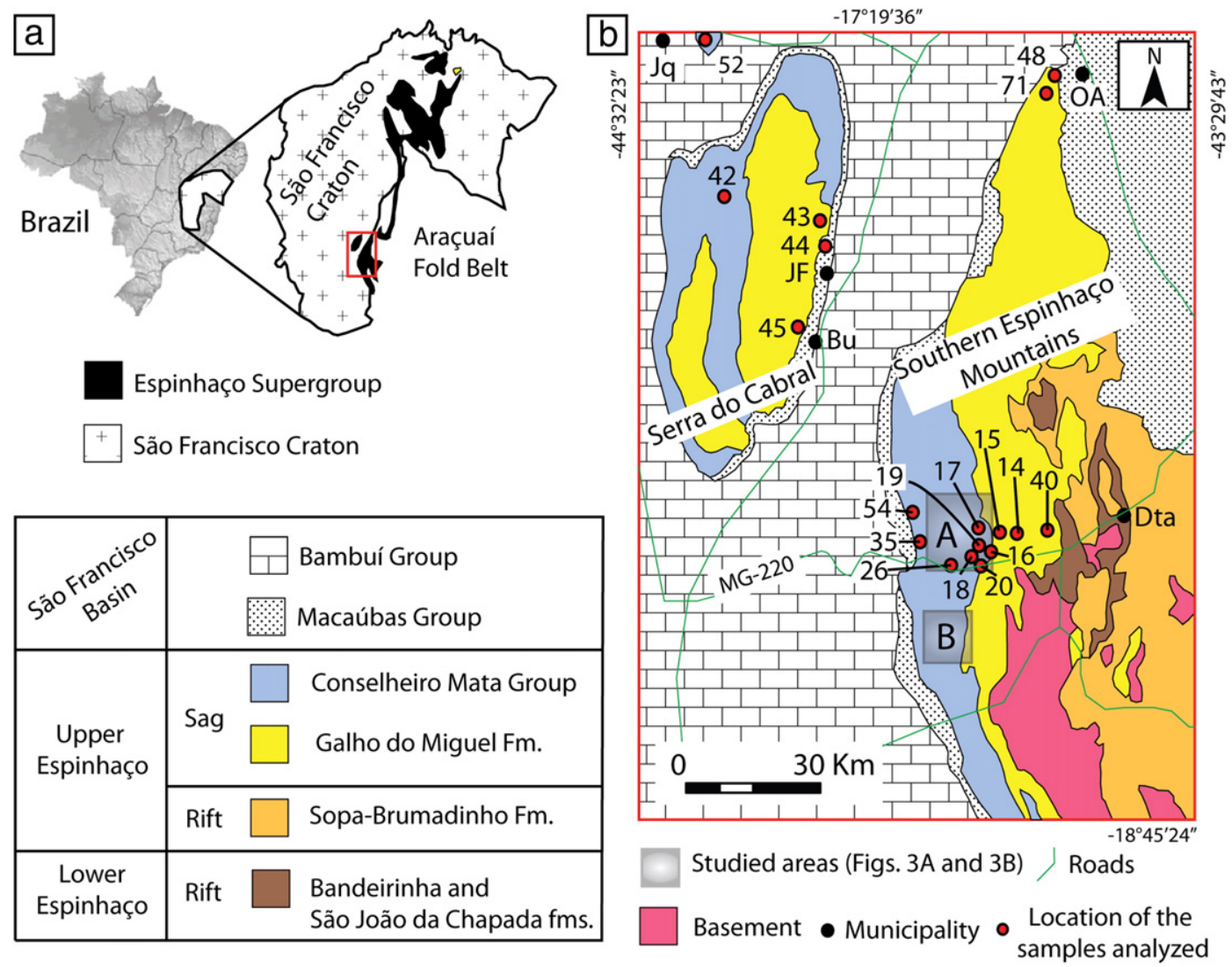

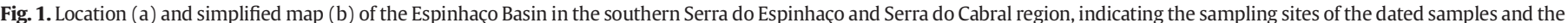

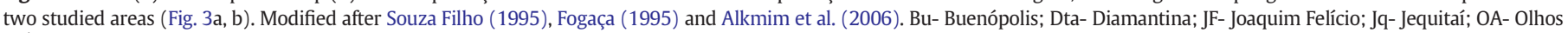
D’Água. 
is preserved in the physiographic regions of the northern Serra do Espinhaço and Chapada Diamantina (Guadagnin et al., 2015). The absence of this sequence in the southern Serra do Espinhaço indicates either erosion or non-deposition; the latter hypothesis assumes that the region remained a topographic high during this period (Chemale et al., 2012).

The Lower Espinhaço Basin (Fig. 1) developed during the Statherian taphrogenesis (Plumb, 1991; Brito Neves et al., 1995). Sedimentation evolved through two distinct rifting stages, which were responsible for the deposition of the Bandeirinha and São João da Chapada formations (Almeida-Abreu, 1993; Santos et al., 2013). The magmatic events of the Lower Espinhaço Basin are represented by 1.77-1.73 Ga acidic alkaline volcanism and plutonism (Brito Neves et al., 1979; Dossin et al., 1993) and K-rich alkaline volcanics (hematite phyllite) dated to 1.71-1.70 Ga (Dossin et al., 1993; Chemale et al., 2012).

The opening of the Upper Espinhaço Basin occurred after 1.2 Ga. This age refers to volcanic zircon grains from the green clay matrix (tuffaceous contribution) of a diamond-bearing conglomerate in the Sopa-Brumadinho Formation (Fig. 2) and marks the time of deposition of this unit during the rift stage of the basin's development (Chemale et al., 2010, 2012). The deposition of the eolian and marine sediments of the Galho do Miguel Formation (Figs. 1, 2) marks an expansion in the area of this basin based on an extrapolation of the limits of the rift and the subsequent transition from mechanical to thermal subsidence (Martins-Neto, 1998). The subsequent sediments represent three marine transgression-regression cycles of the Conselheiro Mata Group (Dossin et al., 1984; Dupont, 1995) (Fig. 2), which are marked by the intercalation of pelitic units (i.e., the Santa Rita, Córrego da Bandeira and Rio Pardo Grande formations) with sand units (i.e., the Córrego dos Borges and Córrego Pereira formations). Despite the large number of published papers that mention the Conselheiro Mata Group, questions regarding its sedimentary provenance and depositional environments remain due to a lack of quantitative analysis integrated with sedimentology.

The Espinhaço Supergroup is cut by basic dykes that have been dated to $0.9 \mathrm{Ga}$ via the U-Pb method performed on crystals of baddeleyite and zircon (Machado et al., 1989) (Fig. 2). The Espinhaço rocks that are exposed along the southern Serra do Espinhaço were affected by the Neoproterozoic to Cambrian west-vergent fold-and-thrust Araçuaí Belt and experienced lower greenschist facies conditions (Chemale et al., 2012, and references therein).

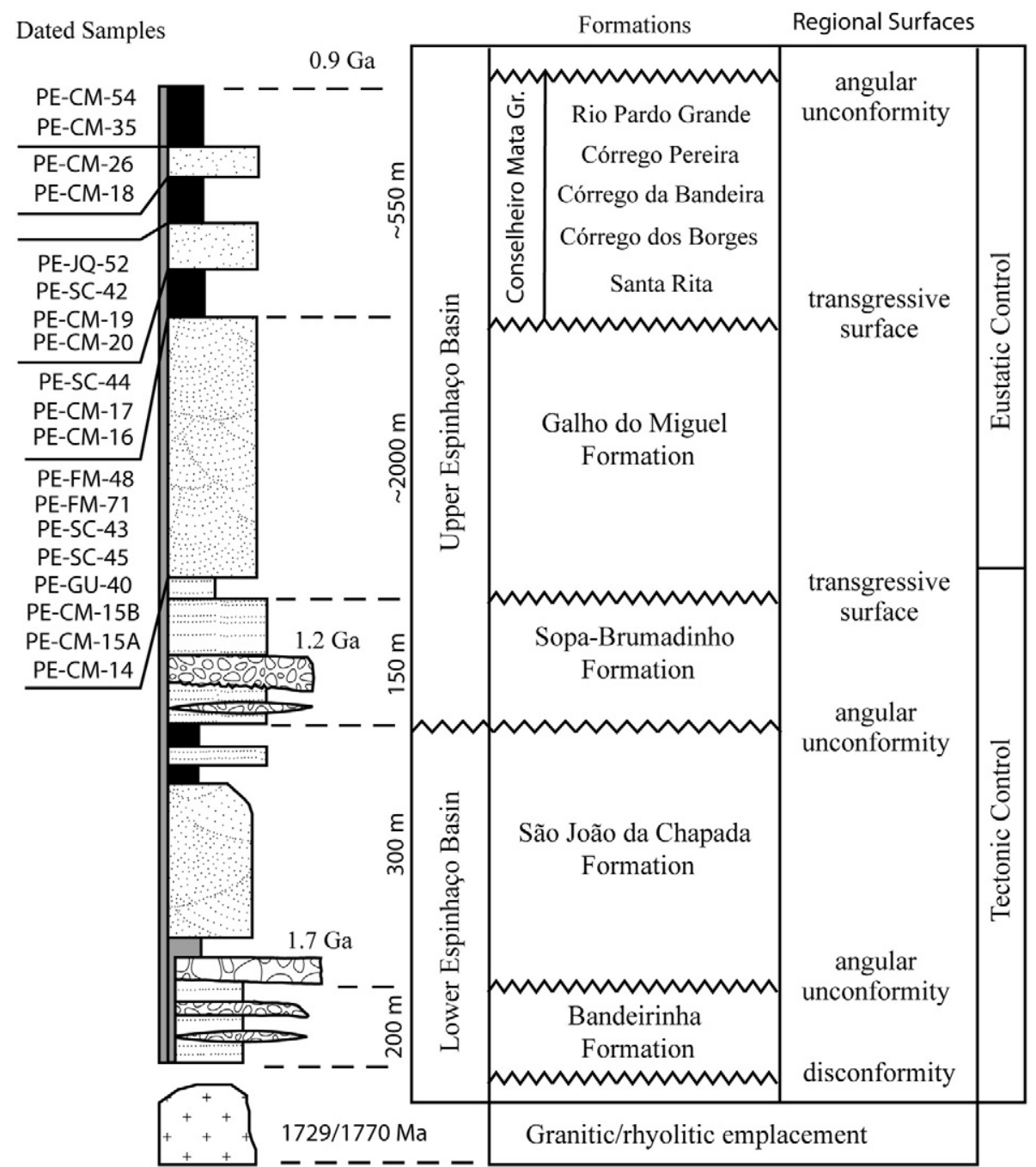

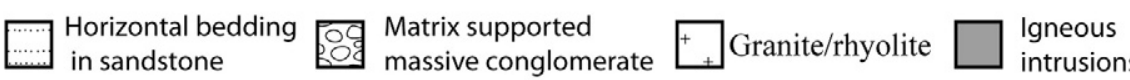
Trough cross-bedded sandstone 


\section{Methods}

For the development of this work, sedimentological and stratigraphic descriptions of sections in the Conselheiro Mata region were completed and complemented with geological mapping at a scale of $1: 25,000$ (Figs. 3a, b, 4) to investigate lateral facies variations. Stratigraphic sections were measured mainly with a Jacob's Staff. The sedimentary facies were recognized based on their texture, sedimentary structures, paleocurrent patterns, set geometry and lateral transitions. Several thin sections were made from the rocks collected along the measured sections to provide a more detailed account of the facies.

From the Galho do Miguel Formation and Conselheiro Mata Group, we analyzed twenty samples for geochemistry and nineteen samples for detrital zircon U-Pb geochronology and conducted a reinterpretation of seismic reflection data (from the Agência Nacional do Petróleo, Gás Natural e Biocombustíveis, previously published by Reis, 2011). The samples were collected in the southern Espinhaço Mountains (west of the Olhos D'Água municipality and along roadcuts of the MG-220 highway) on the eastern edge of the Serra do Cabral and east of the Jequitaí municipality (Fig. 1). We collected four samples of mature sandstones with large-scale tabular and trough cross-bedding (samples PE-CM15A, PE-CM-15B, PE-SC-45 and PE-FM-48) and four with low-angle cross-bedding (samples PE-CM-14, PE-GU-40, PE-SC-43 and PE-FM-71) from the Galho do Miguel Formation. Two samples of pelite (PE-CM-16 and PE-SE-44) and a fine-grained sandstone sample (PE-CM-17) were collected from the Santa Rita Formation. Sandstone samples were also collected from the Córrego Borges (PE-CM-19, PE-CM-20, PE-SC-42 and PE-JQ-52), Córrego Pereira (PE-CM-18 and PE-CM-26) and Rio Pardo Grande (PE-CM-35 and PE-CM-54) formations.

The rock samples were crushed and milled using a jaw crusher. Zircon populations were separated by conventional procedures using hand-panning, a Frantz Isodynamic Magnetic Separator, heavy liquids and sorting by hand under a binocular lens. The zircon grains were

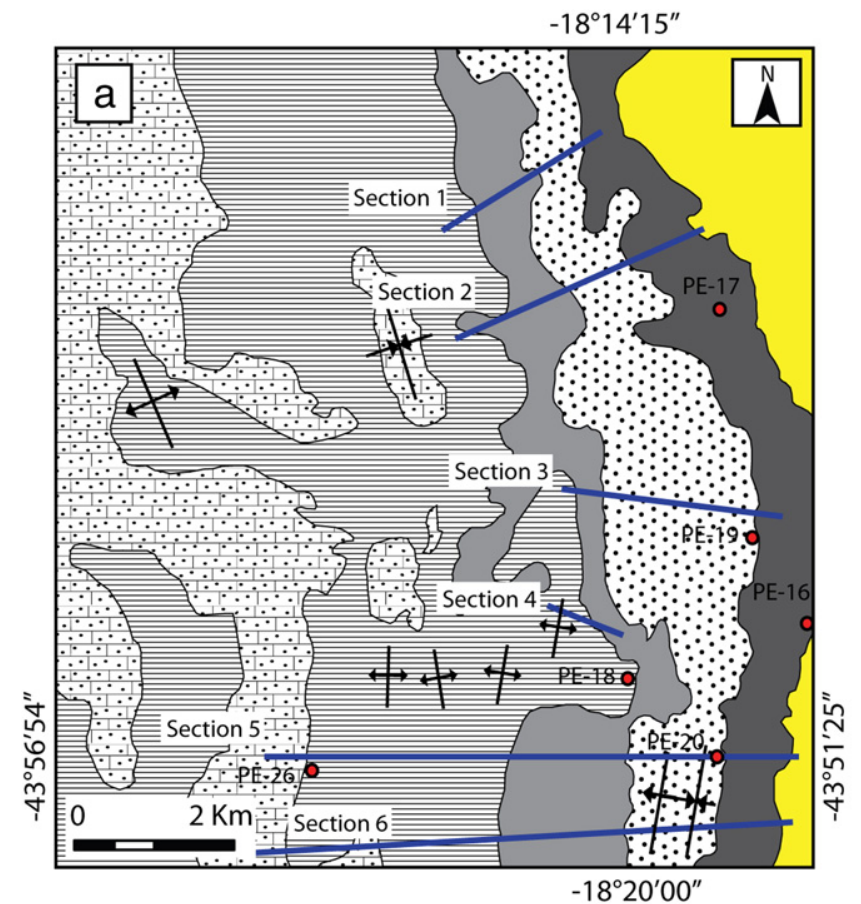

photographed in transmitted and reflected light, imaged using BSE (backscattered electrons) and CL (cathodoluminescence), and dated using a laser ablation microprobe (New Wave UP213) coupled to a MC-ICP-MS (Neptune) at the isotope laboratories of the universities of Brasília and Rio Grande do Sul (Brazil). Isotope data were acquired in static mode with spot sizes of 25 and $40 \mu \mathrm{m}$. Laser-induced elemental fractionation and instrumental mass discrimination were corrected using a reference zircon (GJ-1; Jackson et al., 2004). Two GJ-1 analyses were measured after every ten sample zircon spots. To evaluate the accuracy and precision of the laser-ablation results, we analyzed an internal standard, PAD1, and Temora 2. The external error was calculated based on the propagation error of the GJ-1 mean and the individual sample zircons (or spots). The reproducibility obtained from GJ-1 was $0.6 \%$ for the ${ }^{207} \mathrm{~Pb} /{ }^{206} \mathrm{~Pb}$ ratio and $0.9 \%$ for the ${ }^{206} \mathrm{~Pb} /{ }^{238} \mathrm{U}$ ratio. Details of the analytical procedures can be found in Chemale et al. (2011).

U-Pb SHRIMP (Sensitive High-Resolution Ion Microprobe) zircon geochronology was performed at the Research School of Earth Sciences, Australian National University, using SHRIMP II equipment. The zircon grains were analyzed with a $2-3 \mathrm{nA}, 10 \mathrm{kV}$ primary $\mathrm{O} 2$ beam focused to a $\sim 25$ to $\sim 20 \mu$ m diameter spot. At a mass resolution of $\sim 5500$, the $\mathrm{Pb}$, Th and $\mathrm{U}$ isotopes were resolved from all major interferences. The $\mathrm{U}$ and Th concentrations were determined relative to those measured in the RSES standard SL13. Histograms were prepared with Isoplot/Ex (Ludwig, 2003). For the detrital zircon histogram, we used zircon data with discordance equal to or less than $10 \%$.

\section{Results}

\subsection{Facies associations}

Because the Conselheiro Mata Group is a Mesoproterozoic sequence affected by low-grade metamorphism and deformation during the Brasiliano Orogeny (Dussin, 1994), the metasedimentary facies are
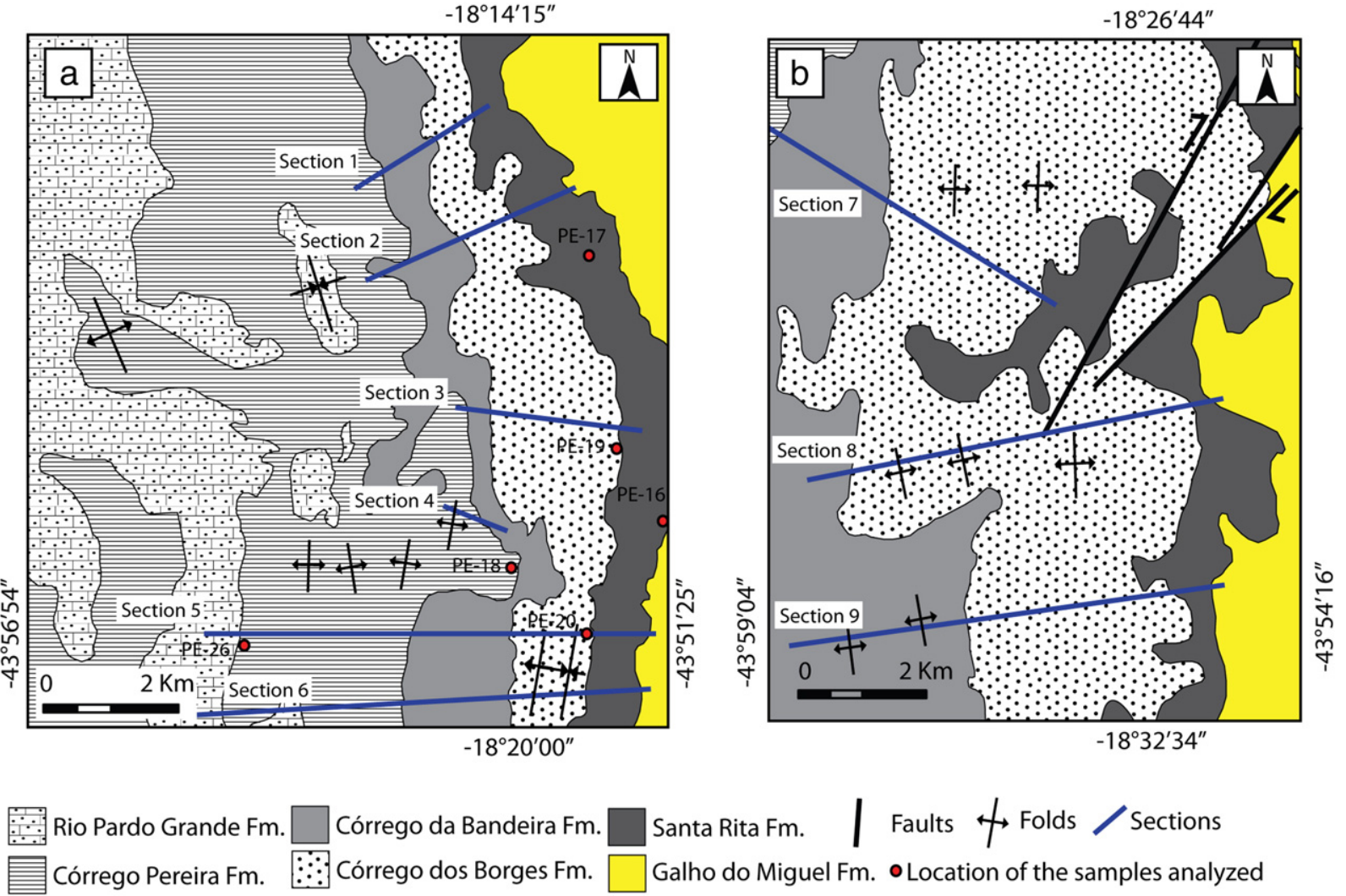

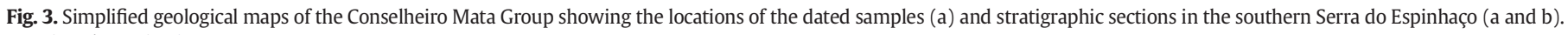
Location shown in Fig. 1. 


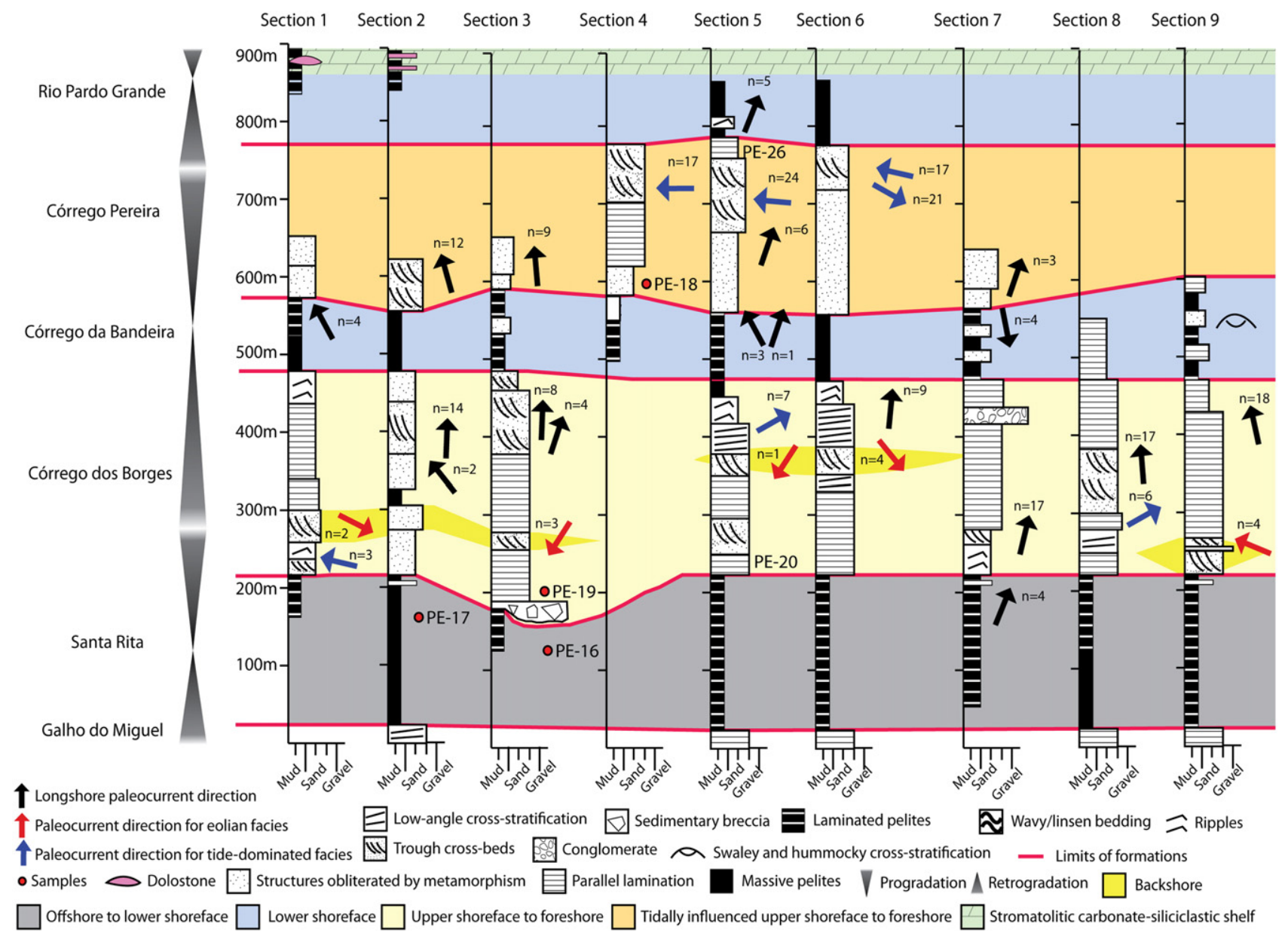

Fig. 4. Correlation of the measured sections in the Conselheiro Mata region. Location shown in Fig. 3. Arrows indicate the mean paleocurrent direction (up: north; down: south).

described with sedimentary nomenclature for practical purposes (Table 1).

The facies associations in the Conselheiro Mata Group were observed in the vicinity of the Conselheiro Mata district belonging to the Diamantina municipality (i.e., where the type sections were defined) and in the Serra do Cabral between Joaquim Felício and Buenópolis. These sites feature excellent and continuous outcrops and allow for the study of lateral and vertical variations in the sedimentary facies. The facies were grouped into six facies associations.

\subsubsection{Facies Association 1 (FA 1): offshore to lower shoreface}

4.1.1.1. Description. FA 1 is mainly composed of laminated and massive siltstones and mudstones with a light-gray color that becomes reddish and even yellow when weathered (Table 1 ). The pelites are primarily composed of sericite and quartz. Magnetite crystals altered to martite occur sparsely, as observed by Fogaça (1995). Toward the top of FA 1, siltstones are interbedded with tabular sand beds of centimeter-scale thicknesses $(<10 \mathrm{~cm}$ thick in Conselheiro Mata and $<50 \mathrm{~cm}$ in the Serra do Cabral). The sandstones are beige, fine- to very fine-grained, well-sorted, subrounded, composed of quartz with some mica and feldspar, and exhibit wave ripples and gradational contacts at the top and bottom. The presence of hummocky cross-stratification in the sandstones of the Santa Rita Formation has been described in the southern Serra do Espinhaço (Dossin et al., 1990). Toward the top of FA 1, small sand dykes were observed in the siltstones at the top of the Santa Rita Formation (Schöll and Fogaça, 1979).
4.1.1.2. Interpretation. FA 1 records an upward increase in the energy and frequency of sediment deposition based on the upward-coarsening grain size coupled with increasing sandstone interbeds. The basal portions of FA 1, which consist essentially of horizontal, planar-laminated pelites, indicate low-energy deposition, interpreted as the fallout of suspended fine material deposited during fair-weather periods, most likely below the storm wave base, which is typical of offshore conditions (Clifton, 2006). At the top of FA 1, the appearance of sand beds (Fig. 4) marks the transition from offshore to lower shoreface conditions. The increased quantity of sandstones toward the top of FA 1 may indicate that storm waves removed sand from the proximal portions of the basin due to a relative sea-level fall (i.e., deposition above the storm wave base). The injection of sand dykes into the pelites in FA 1 most likely resulted from liquefaction during seismic events (Schöll, 1980; Fernandes et al., 2007). This interpretation is corroborated by the deposition of intraformational breccias and synsedimentary deformation structures (FA 2) above the pelitic facies.

\subsubsection{Facies Association 2 (FA 2): upper shoreface to foreshore}

4.1.2.1. Description. The pelites of FA 1 transition gradually into an interval composed mainly of plane-parallel-stratified sandstone, which is designated Facies Association 2 (Table 1). FA 2 is composed of sandstones, conglomerates and massive sedimentary breccias. The sandstones are white and beige; their composition ranges from pure quartz to arkosic and micaceous, and they contain rare dispersed magnetite crystals that have altered to martite. The mineral grains are fine- to medium-grained, moderately to well sorted and subrounded 
Table 1

Description and interpretation of the sedimentary facies of the Conselheiro Mata Group.

\begin{tabular}{|c|c|c|c|c|}
\hline & & Description & Interpretation & Formation \\
\hline Facies Association 1 & offshore to lower shoreface & $\begin{array}{l}\text { Laminated and massive siltstone/mudstone composed primarily } \\
\text { of quartz and sericite. } \\
\text { Fine- to very fine-grained sandstone with wave ripples and } \\
\text { gradational contacts at the top and bottom. Small sand dykes in } \\
\text { pelites toward the top of FA } 1 \text {. }\end{array}$ & $\begin{array}{l}\text { These pelite beds represent fallout of suspended fine sediments } \\
\text { in an offshore environment. } \\
\text { Deposited above storm wave base. Quiescent periods followed by } \\
\text { episodic sediment supply. The sand dykes most likely resulted } \\
\text { from liquefaction during seismic events. }\end{array}$ & Santa Rita \\
\hline Facies Association 2 & upper shoreface to foreshore & $\begin{array}{l}\text { Massive sedimentary breccias and conglomerate (massive or } \\
\text { normally graded, clast-supported). } \\
\text { Plane-parallel-stratified and low-angle cross-bedding sandstone. } \\
\text { Symmetrical and asymmetrical ripples and small- to medium-scale } \\
\text { tabular and trough cross-bedding occur secondarily. }\end{array}$ & $\begin{array}{l}\text { Deposited by submarine fans. Reworking of previously lithified } \\
\text { sandstones of the Galho do Miguel Formation, FA } 1 \text { and/or FA } 2 \text {. } \\
\text { Wave swash in a beach environment along low-angle dipping to } \\
\text { sub-horizontal depositional surfaces in the foreshore area. Migration } \\
\text { of subaqueous 2D and 3D dunes in the upper shoreface. }\end{array}$ & Córrego dos Borges \\
\hline Facies Association 3 & coastal desert environment & $\begin{array}{l}\text { Sandstones with large-scale tabular and trough cross-bedding. } \\
\text { Locally exhibits alternating thin laminae of white and gray sand. } \\
\text { Massive and horizontally laminated, fine- to medium-grained } \\
\text { sandstones. Layers of facetted pebbles occur secondarily. }\end{array}$ & $\begin{array}{l}\text { Eolian dunes with straight and sinuous crests. Cross-bedding produced } \\
\text { by grain fall and grain flow processes. } \\
\text { Dry deflationary interdune deposits. }\end{array}$ & Córrego dos Borges \\
\hline Facies Association 4 & $\begin{array}{l}\text { tidally influenced upper } \\
\text { shoreface to foreshore }\end{array}$ & $\begin{array}{l}\text { Sandstones with small-scale tabular and trough cross-bedding. } \\
\text { Bimodal paleocurrent distributions forming herringbone } \\
\text { cross-bedding. } \\
\text { Sandstones with planar horizontal stratification, flaser lamination, } \\
\text { symmetric and asymmetric ripples. } \\
\text { Sandstones with tidal bundles and tidal bundles with } \\
\text { sigmoid-shaped cross-strata. }\end{array}$ & $\begin{array}{l}\text { Migration of subaqueous 2D and 3D dunes during ebb- and flood-tides in } \\
\text { the upper shoreface. } \\
\text { Wave swash in a beach environment along sub-horizontal depositional } \\
\text { surfaces in the foreshore area. } \\
\text { Cycles of neap-spring tides. The mud drapes in tidal-bundles represent a } \\
\text { decrease in energy during neap tides in some cycles. }\end{array}$ & Córrego Pereira \\
\hline Facies Association 5 & lower shoreface & $\begin{array}{l}\text { Sandstone with convolute lamination and sand dykes. } \\
\text { Massive and hummocky/swaley stratified sandstone. Sandstones } \\
\text { with small-scale truncated wave-ripple and medium-scale trough } \\
\text { cross-bedding are less frequent. }\end{array}$ & $\begin{array}{l}\text { High sedimentation rates and liquefaction of sand beds under shock loading. } \\
\text { Combination of unidirectional and oscillatory flows generated by storm } \\
\text { waves in lower shoreface. }\end{array}$ & $\begin{array}{l}\text { Rio Pardo Grande } \\
\text { Córrego da Bandeira Rio Pardo Grande }\end{array}$ \\
\hline Facies Association 6 & $\begin{array}{l}\text { stromatolitic carbonate- } \\
\text { siliciclastic shelf } 1\end{array}$ & $\begin{array}{l}\text { Laminated and massive siltstone/mudstone } \\
\text { Pelites that may or may not contain layers of carbonate. }\end{array}$ & $\begin{array}{l}\text { Fallout of suspended fine sediments in a lower shoreface environment. } \\
\text { Fallout of suspended fine sediments in a upper shoreface environment, } \\
\text { probably a result of reduced siliciclastic influx. }\end{array}$ & $\begin{array}{l}\text { Córrego da Bandeira Rio Pardo Grande } \\
\text { Córrego da Bandeira Rio Pardo Grande }\end{array}$ \\
\hline & & $\begin{array}{l}\text { Massive and laminated dolostone. Layers with stratiform } \\
\text { stromatolites with flat and crenulated lamination. }\end{array}$ & Subaqueous precipitation. & Rio Pardo Grande \\
\hline
\end{tabular}



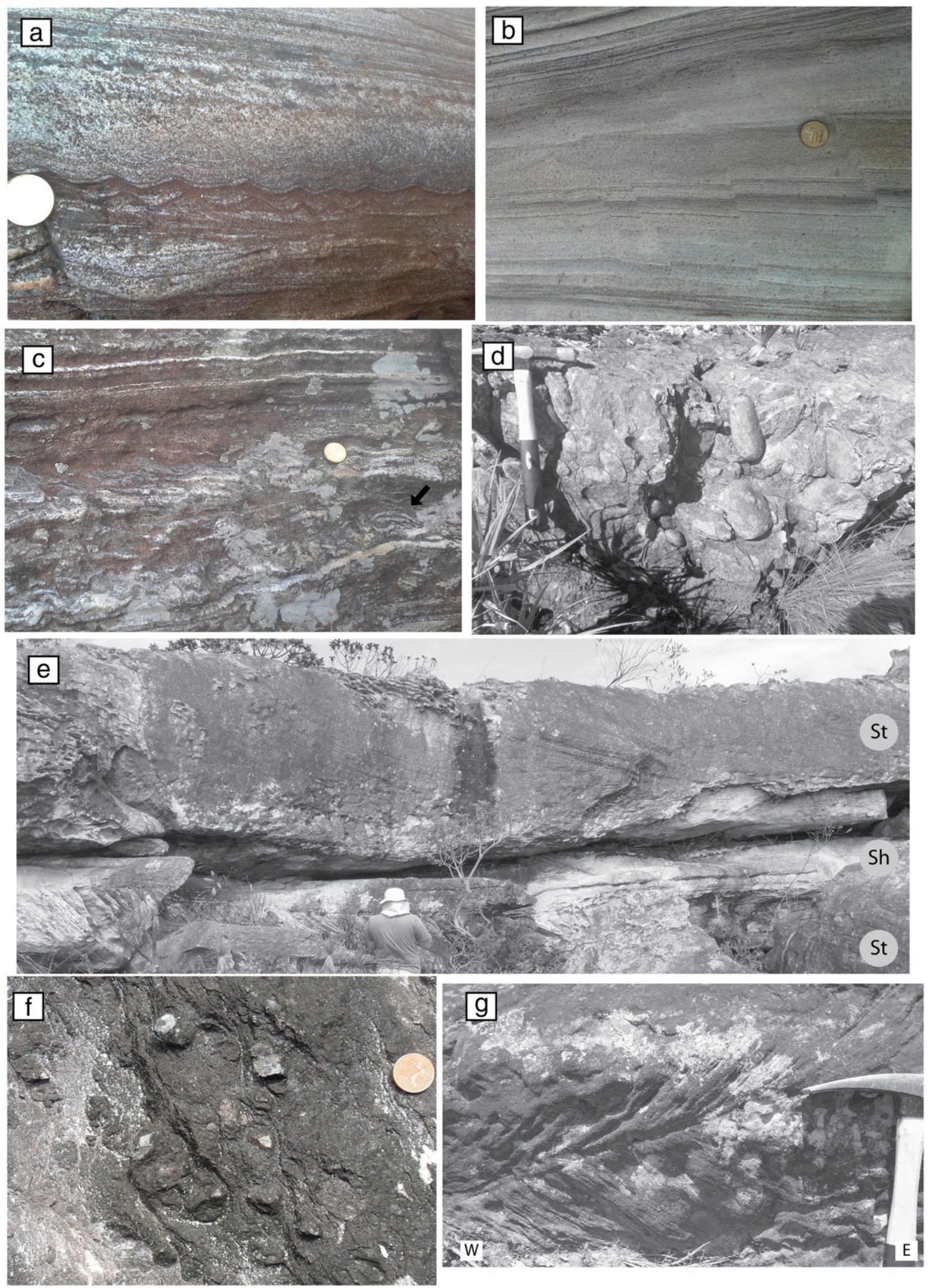

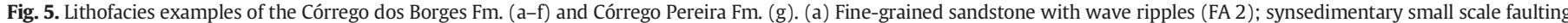

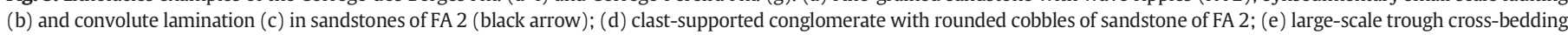

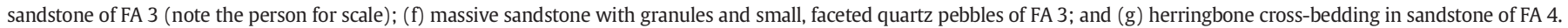

sand. Horizontal planar stratification predominates, but symmetrical and asymmetrical ripples (Fig. 5a), low-angle cross-bedding and small- to medium-scale tabular and trough cross-bedding occur secondarily, indicating a predominantly north-south paleoflow (Fig. 7).
Evidence for synsedimentary deformation is seen in folded and faulted foresets (Fig. 5b, c), where the deformed horizons can reach $1 \mathrm{~m}$ in thickness. The sedimentary breccias of FA 2 have abrupt lateral and vertical contacts with the surrounding sandstone, reach up to $10 \mathrm{~m}$ 

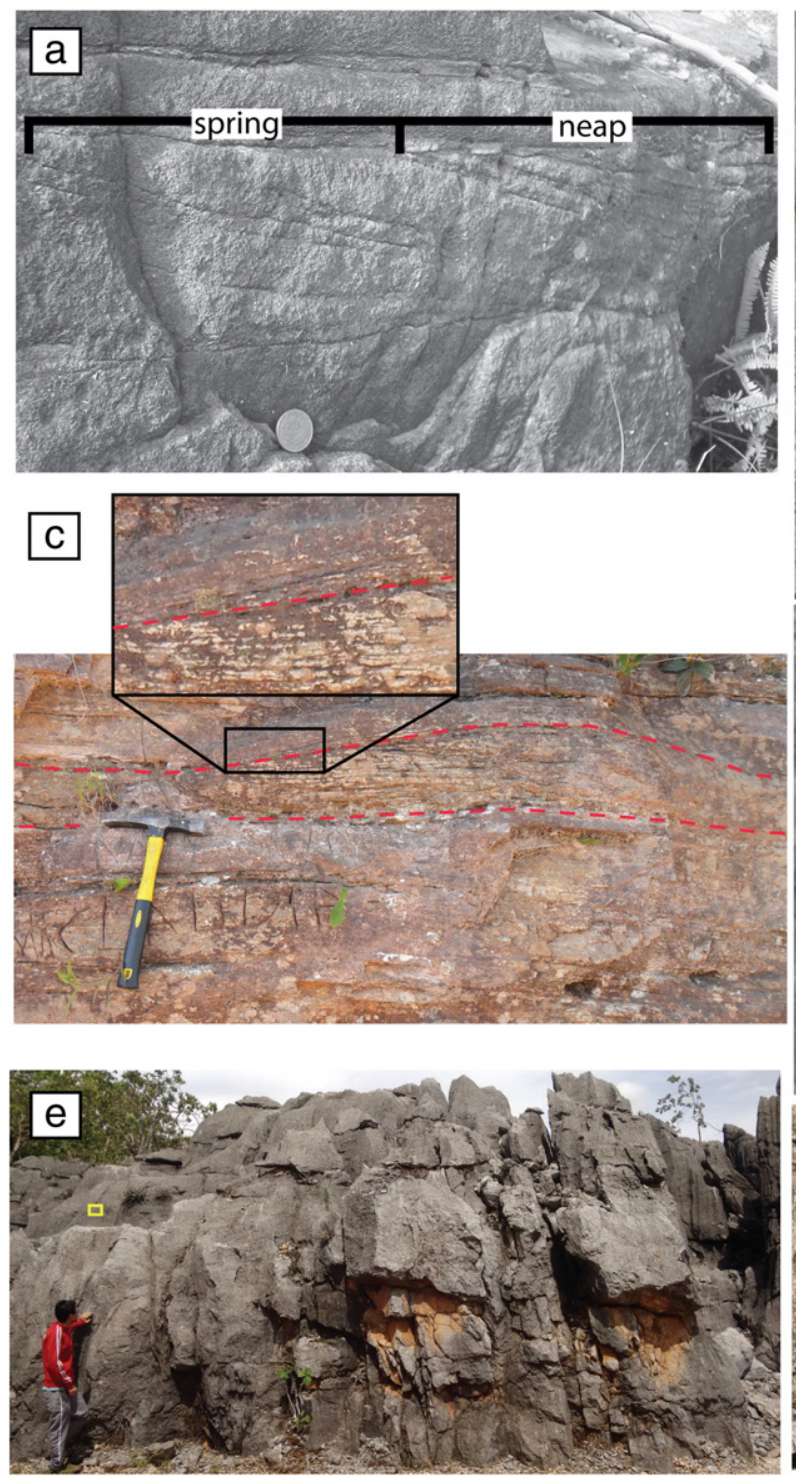
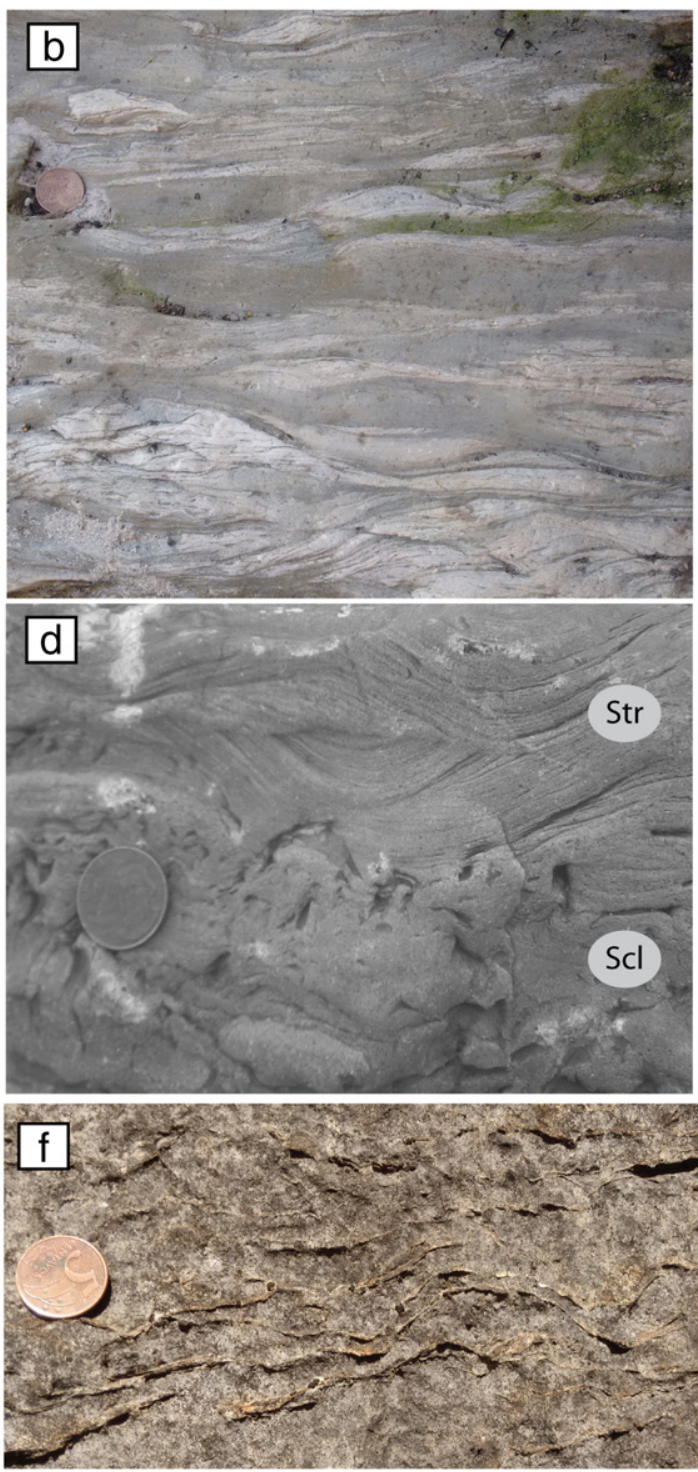

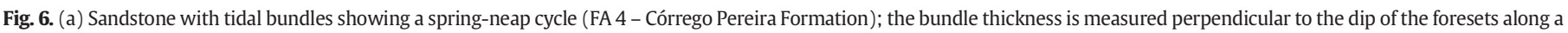

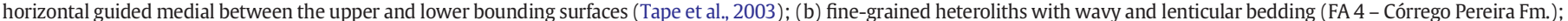

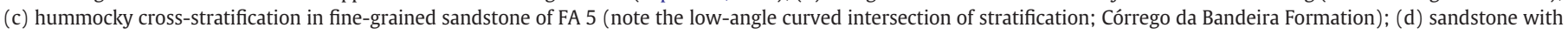

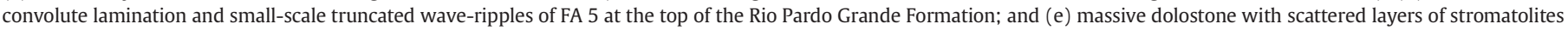
(yellow box) with crenulated lamination (f) (FA 6 - Rio Pardo Grande Fm.). Str- sandstones with small-scale truncated wave-ripple; Scl- sandstone with convolute lamination.

thick, and are massive and clast-supported, with variably sized angular clasts of laminated white sandstones ranging from cobbles to boulders. The monomictic nature of the sedimentary breccias has been observed by Fogaça (1995), who also identified features of erosive channels. The rare conglomerate bodies have lenticular geometries, can reach thicknesses of up to $3 \mathrm{~m}$, and are massive or normally graded and clast supported, with rounded cobbles of sandstone (Fig. 5d).

4.1.2.2. Interpretation. The base level affected by the action of fair-weather waves is proposed by Leckie and Krystinik (1989) to be the lower limit of the upper shoreface. This zone is affected by longshore currents, rip currents and breaking waves in the surf zone. Such processes operating in the upper shoreface result in the formation of tabular and trough cross-bedded sandstones in response to the migration of subaqueous 2D and 3D dunes, respectively (Clifton, 2006). Sandstones with abundant horizontal planar stratification and low-angle cross-bedding commonly represent wave swash in a beach environment along low-angle to sub-horizontal depositional surfaces in the foreshore area (Clifton, 2006). Therefore, the formation of the sandstone described above most likely represents deposition in shallow water in the transition zone between the upper shoreface and foreshore. An approximately north-south-oriented coastline is inferred by the symmetrical ripples with this orientation. The mainly north and south orientations of the paleocurrent directions based on the subaqueous dunes suggest that deposition occurred during the action of longshore drift due to the obliquity of the waves against the shoreline.

The deposition of intraformational sedimentary breccias suggests a reworking of previously lithified sediments of the Galho do Miguel Formation or FA 1 and may represent a period of tectonic instability leading to the formation of submarine fans in the basin, particularly at the interface between FA 1 and FA 2, where the clastic dykes were noted (above).

\subsubsection{Facies Association 3 (FA 3): coastal desert environment}

4.1.3.1. Description. FA 3 comprises two intercalated sedimentary facies that reach a thickness of approximately $40 \mathrm{~m}$ (Table 1 ). The first facies 


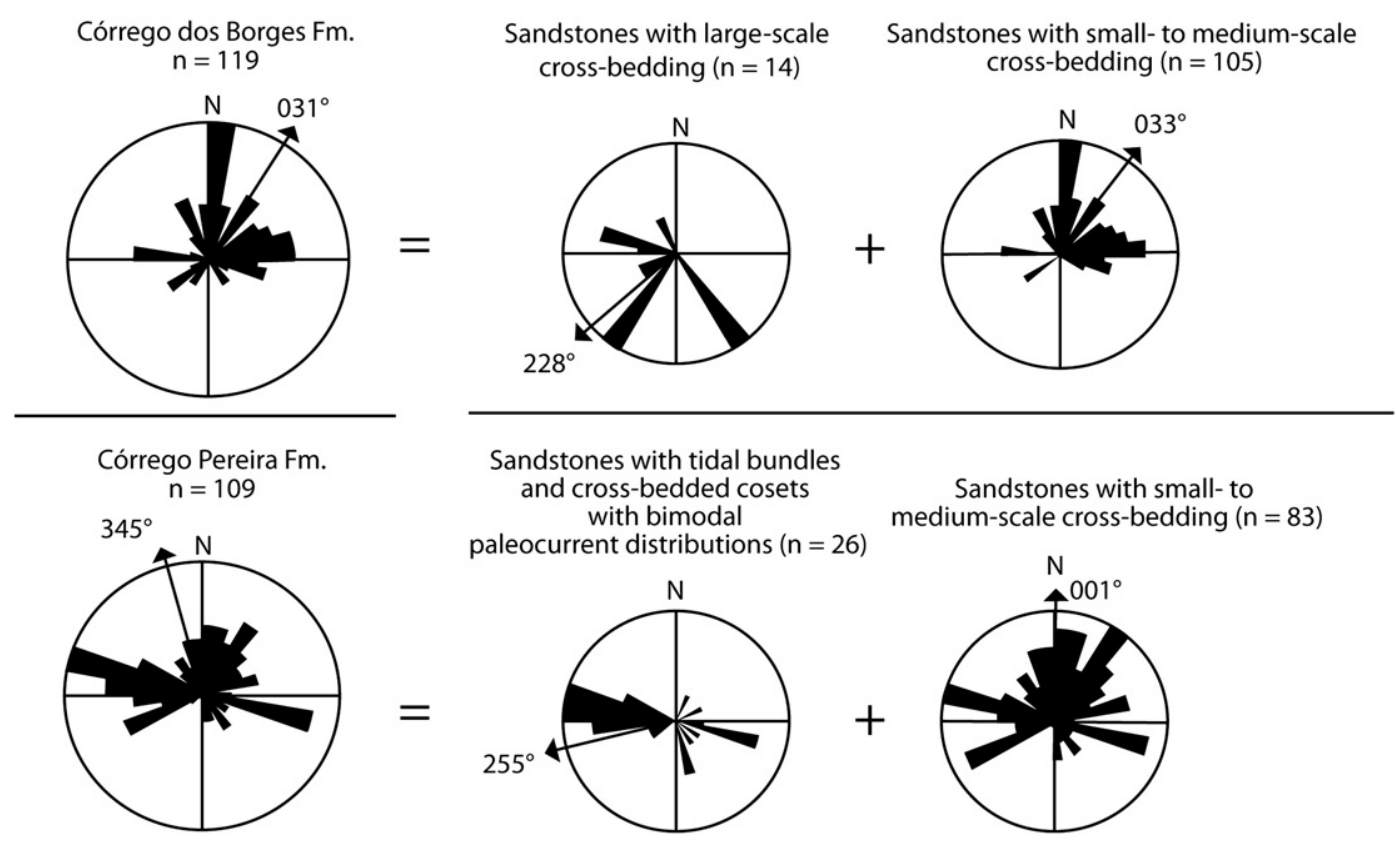

Fig. 7. Paleocurrent data of the Córrego dos Borges and Córrego Pereira formations plotted on rose diagrams.

comprises mineralogically and texturally mature sandstones. These sandstones are beige colored, and the predominantly medium-sized sand grains are generally well sorted and rounded. The sandstone beds exhibit tabular and lenticular geometry with sets ranging between 2 and $3 \mathrm{~m}$ thick. However, the main features of this facies are the presence of large-scale (2-3 m thick) tabular and trough crossbedding with dips of approximately $30^{\circ}$ (Fig. 5e) and paleocurrent directions to the southwest and southeast, which are quite distinct from the other facies associations (Figs. 4, 6, 7). The trough cross-bedding locally exhibits alternating thin laminae of white and gray sand. The second facies is composed of massive, poorly sorted, light-gray sandstone with predominantly medium to coarse grain sizes. This sandstone also contains granules and small, faceted quartz pebbles scattered throughout (Fig. 5f). Generally, FA 3 is positioned in the intermediate portions of the Córrego dos Borges Formation (i.e., in the middle of FA 2). However, in stratigraphic Section 9, FA 3 directly overlies the Santa Rita Formation (i.e., on FA 1; Fig. 4).

4.1.3.2. Interpretation. The sandstones with large-scale cross-bedding most likely result from the migration of large eolian dunes with straight and sinuous crests (2D and 3D). The maturity of the sandstone with well-sorted and well-rounded grains is typical in many coastal deposits and, together with the large-scale and high-angle cross-bedding (produced by grain fall and grain flow processes), indicate the presence of eolian dunes with a well-developed slip face (Inman et al., 1966; Fryberger and Schenk, 1988; Mountney, 2006). The small, faceted pebbles in the massive sandstones most likely represent ventifacts formed in deflationary interdune areas. The conditions that favor the formation of ventifacts include a supply of loose sediment within an appropriate size range, relatively strong winds and appropriate direction, ground surface stability and exposed clast surfaces (pebble input) (Laity, 1994; Knight, 2008). Most ventifacts in modern environments are found in desert pavements (Cook et al., 1993; Livingstone and Warren, 1996). FA 3 is interpreted to represent a coastal desert environment, similar to the Namib Desert. In stratigraphic Section 9 (Fig. 4), the eolian deposits directly overlie offshore/lower shoreface deposits, indicating a local disconformity formed by subaerial exposure.
4.1.4. Facies Association 4 (FA 4): tidally influenced upper shoreface to foreshore

4.1.4.1. Description. FA 4 is present across almost the entire Córrego Pereira Formation and is modestly expressed in the Córrego dos Borges Formation. FA 4 consists of sandy bodies with lenticular and tabular geometry, predominantly small-scale tabular and trough cross-bedding (sets ranging from 10 to $50 \mathrm{~cm}$ defined by reactivation surfaces), generally forming herringbone cross-bedding, and bimodal paleocurrent patterns that are predominantly to the west and east (Figs. 5g, 7; Table 1). The grains of this facies range in size from fine to medium sand, are moderately to well sorted, and are sub-angular to sub-rounded. This facies rarely presents mud-draped foresets. Mineralogically, the sandstone consists of quartz and may contain varying amounts of plagioclase, mica and dispersed opaque minerals. The color varies from white to beige. Planar horizontal stratification, symmetric ripple marks oriented north-south, asymmetric ripple marks, and wavy and lenticular lamination occur rarely in FA 4 (Fig. 6b). The perpendicular direction of the asymmetric ripples with respect to the wave ripples often forms interference ripple marks.

Tabular and trough cross-bedding with sigmoidal cross-strata exhibit foreset thickening-thinning patterns. These facies are composed of medium- to coarse-grained sandstones, are moderately sorted and in some cases contain thin mud drapes (Fig. 6a). The sigmoidal crossbeds are medium in scale (sets of approximately $1 \mathrm{~m}$ ) and feature progressive thinning toward the downdip direction, moderate dipping (approximately $20^{\circ}$ ) and reversals in paleocurrent directions.

4.1.4.2. Interpretation. Several authors (e.g., Davis and Hayes, 1984; Anthony and Orford, 2002) suggest that coastal systems can be classified into two main types: wave dominated and tide dominated. We interpret FA 4 as representative of tide-dominated shallow-marine systems. The presence of wave ripples, especially in the Serra do Cabral region, indicates the direct influence of waves and a north-southoriented coastline, whereas the herringbone cross-bedding indicates ebb and flood tidal currents of approximately equal magnitude oriented perpendicular to the coastline (i.e., tidal currents to the east and west). 
The heterolithic bedding indicates repeated fluctuations in the energy regime, which are usually linked to tide-dominated depositional environments (Reineck and Singh, 1980).

The variation in the thickness of the foresets in certain outcrops with cross-beds represents cycles of neap-spring tides, in which relatively thin bundles are deposited during neap tides and relatively thick bundles are deposited during spring tides (Nio and Yang, 1991; Tape et al., 2003). The mud drapes in tidal bundles represent a decrease in energy (carrying capacity and competence) during neap tides in certain cycles. According to Kreisa and Moiola (1986), sigmoidal cross-stratification is formed as a result of the rapid transport and deposition of sediments during episodes of intense tidal flow. This type of flow in the Conselheiro Mata Group appears to be ephemeral and short lived because sigmoidal cross-stratification is rare and relatively thin bedded. The longshore currents have a secondary influence in FA 4, generating some cross-stratification and asymmetrical ripples with paleocurrent directions to the north and south.

\subsubsection{Facies Association 5 (FA 5): lower shoreface}

4.1.5.1. Description. The transition from upper shoreface (FA 2, FA 4) to lower shoreface conditions (FA 5) is gradual. FA 5 is mainly composed of pelites and quartz-sandy facies, which form rhythmites with a pelite/sandstone ratio that is commonly 1:1 in the Córrego da Bandeira Formation (Table 1). The pelitic beds can reach thicknesses of up to $15 \mathrm{~m}$ with sharp bed tops. These beds are predominantly massive, although lamination may occur rarely, and typically feature silt-sized grains. Magnetite crystals altered to martite occur sparsely and lend a gray and red color to the pelites. The sandstones that are interbedded with pelites predominantly feature fine-grained, well-sorted, and subrounded sand. These sandstones range from white to gray and can be massive or display medium-scale hummocky and swaley crossstratification (HCS and SCS, respectively; Fig. 6c). Most beds consist of low-angle cross-stratification, have tabular or pinch and swell geometry, decrease by as much as 35\% in thickness (commonly $25 \mathrm{~cm}$ average thickness), and define hummocks of antiform relief with wavelengths between 1.3 and $2 \mathrm{~m}$. Asymmetrical ripples are rarely preserved on upper surfaces. Laminated micaceous sandstones, sandstones with sand dykes, convolute laminations, small-scale truncated wave ripples (Fig. 6d) and medium-scale trough cross-bedding also occur but are uncommon.

4.1.5.2. Interpretation. This facies association is interpreted to have been deposited between a fair-weather wave base and a storm wave base (Dott and Bourgeois, 1982; Walker, 1984; Leckie and Krystinik, 1989) in lower shoreface conditions. According to Galloway and Hobday (1996), sediments along the lower shoreface experience greater influence from storms and lesser influence from shorter-period fairweather waves. The sandy facies described above (HCS, SCS and trough cross-bedding) are usually formed under a combination of unidirectional and oscillatory flow conditions caused by storm waves, indicating a high-energy context (Swift et al., 1983; Southard et al., 1990; Duke et al., 1991; DeCelles and Cavazza, 1992; Dumas and Arnott, 2006).

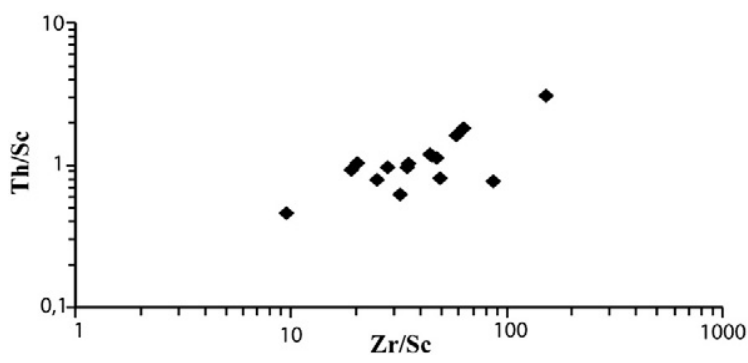

Fig. 8. $\mathrm{Zr} / \mathrm{Sc}$ versus $\mathrm{Th} / \mathrm{Sc}$ plot of the Galho do Miguel Formation and Conselheiro Mata Group.
Additionally, the presence of rhythmites, sandstones with convolute laminations, sand dykes and pelites/SCS intercalations is usually linked to a high-frequency episodic sediment supply (Reineck and Singh, 1980).

\subsubsection{Facies Association 6 (FA 6): Stromatolitic carbonate-siliciclastic shelf}

4.1.6.1. Description. FA 5 transitions gradually into an interval composed of mixed siliciclastic-chemical sedimentary rocks designated FA 6. This facies association occurs only in the southern Serra do Espinhaço and includes three main facies: a) pelite containing layers of carbonate, b) massive dolostone, and c) laminate dolostone. The pelite is thinly laminated, ranges from light gray to dark gray, and comprises quartz, sericite and thin layers of dolomitic limestone, although lenses (2-3 m) of limestone may occur rarely (Dossin et al., 1990). The presence of centimeter-scale layers of carbonate in the pelites has been reported only in the Rio Pardo Grande Formation in the Conselheiro Mata region (Pflug, 1968; Schöll and Fogaça, 1979; Fogaça, 1995), but Lopes (2012) also identified carbonates in the Córrego da Bandeira Formation on the northwestern edge of the Serra do Cabral.

Massive gray dolostone occurs toward the top of the Rio Pardo Grande Formation and can reach thicknesses of up to $40 \mathrm{~m}$ (Batista et al., 1986; Fogaça, 1995) (Fig. 6e). Most of the primary structures have been obliterated by metamorphic recrystallization and deformation. Layers with stratiform stromatolites with flat and crenulated lamination (Fraga et al., 2014) occur scattered randomly throughout the massive dolostone (Fig. 6f).

4.1.6.2. Interpretation. The pelites are the product of the fallout of suspended fine sediments. The carbonate layers in the pelite rocks were most likely produced biologically or via biochemical mediation because this facies is overlain by dolostone with stromatolites. According to Dossin et al. (1990), these layers were deposited in a shallow marine environment, implying a substantial reduction in siliciclastic influx. Therefore, FA 6 is interpreted as resulting from a mixed carbonatesiliciclastic shelf (Garcia and Uhlein, 1987; Dupont, 1995). According to Droxler and Schlager (1985), the deposition rates of carbonate sediments are higher during sea-level highstands, a stage compatible with part of the Córrego da Bandeira and Rio Pardo Grande formations following an initial transgression phase.

\subsection{Analytical results}

The locations and complete results of the geochemistry and U-Pb detrital zircon geochronology are shown in Appendices A (electronic supplementary material) and in the charts in Figs. 8-12.

$\mathrm{The} \mathrm{Th} / \mathrm{Sc}$ and $\mathrm{Zr} / \mathrm{Sc}$ ratios exhibit large variations in the analyzed samples. In the pelitic samples of the Santa Rita Formation (PE-CM-16, PE-SC-44 and PE-SC-46) and sandstone samples of the Galho do Miguel Formation (PE-GU-40, PE-SC-43 and PE-FM-48) and Córrego dos Borges Formation (PE-CM-19 and PE-CM-21), the Th/Sc ratio is greater than 1 , and almost all samples have a $\mathrm{Zr} / \mathrm{Sc}$ ratio greater than 10 (Fig. 8). The chondrite-normalized REE patterns for the samples from the Galho do Miguel Formation and Conselheiro Mata Group are shown in Fig. 9. Because sandstones with high $\mathrm{Zr}$ contents ( $400 \pm 200 \mathrm{ppm}$ ) may indicate the enrichment of heavy minerals (i.e., zircon), which characteristically have a abundant REEs (Gromet et al., 1984; McLennan, 1989), the samples with $\mathrm{Zr}$ contents of $400 \pm 200$ ppm (i.e., PE-16, PE-17, PE-44 and PE-21) were not included in the graph shown in Fig. 9 to avoid bias.

The samples from the Galho do Miguel Formation and all the units from the Conselheiro Mata Group (with the exception of the Córrego da Bandeira Formation, which was not analyzed) show a steep LREE pattern, a relatively flat HREE pattern and significant enrichment in LREEs ( 6-73 times greater than chondrite; Fig. 9). All the samples have moderately negative Eu anomalies, with $\mathrm{Eu} / \mathrm{Eu}^{*}$ values of 


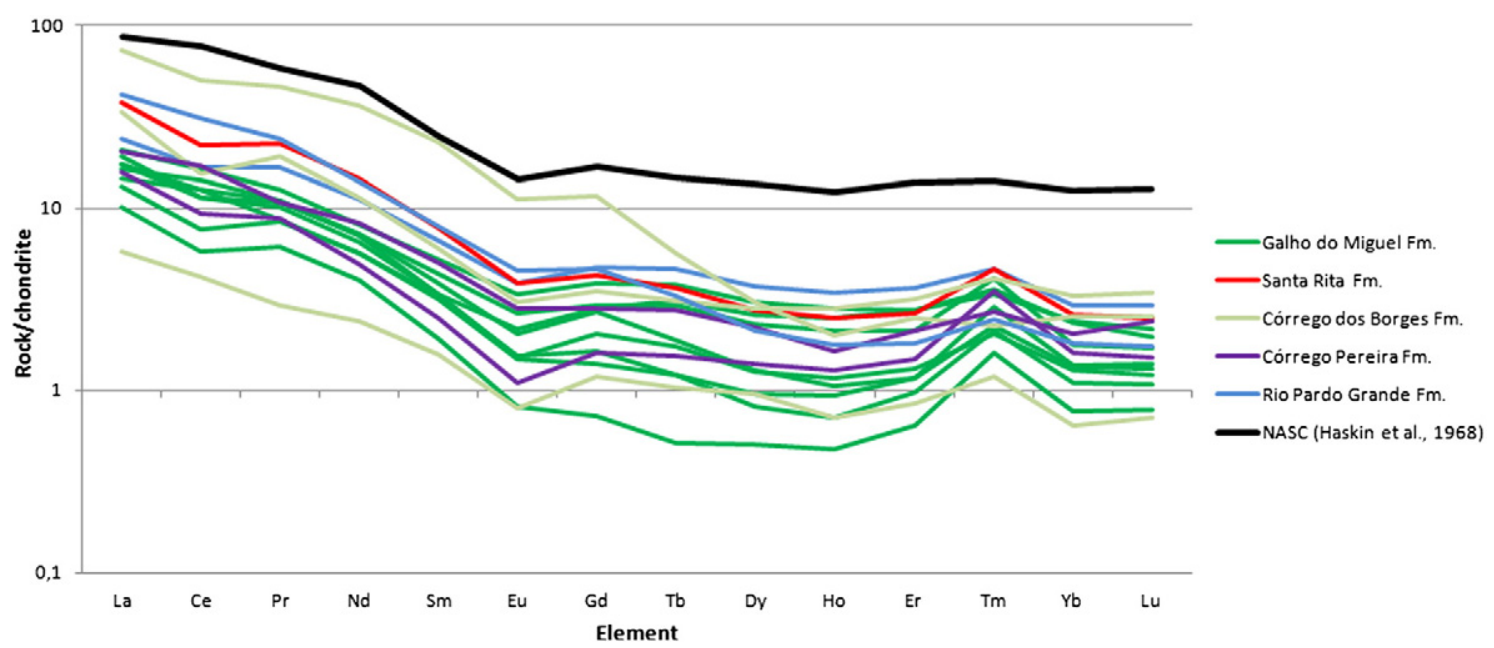

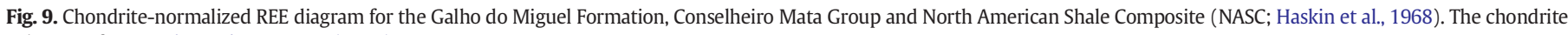
values are from Taylor and McLennan (1985).

0.54-0.79. The REE pattern is similar to that of the NASC (Haskin et al., 1968). However, the REE abundances identified in the samples are depleted in comparison to the NASC's composition, most likely due to the quartz dilution effect (Taylor and McLennan, 1985).
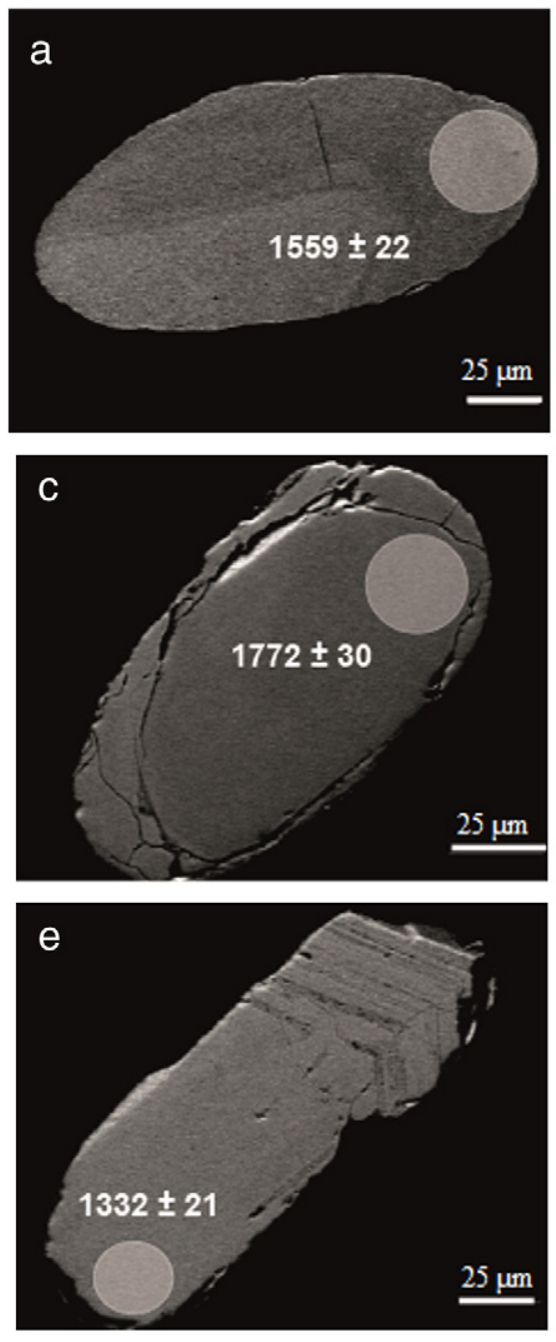

The Galho do Miguel Formation is dominated by Rhyacian (Plumb, $1991)$ zircon grains $(2.05-2.3 \mathrm{Ga}$ ) with a main peak at $2.1 \mathrm{Ga}$ that is well marked in all the samples. Minor peaks occur at $1832 \mathrm{Ma}$ $2405 \mathrm{Ma}, 2679 \mathrm{Ma}$ and $3.4 \mathrm{Ga}$ (Figs. 10a, 11a). The youngest ages
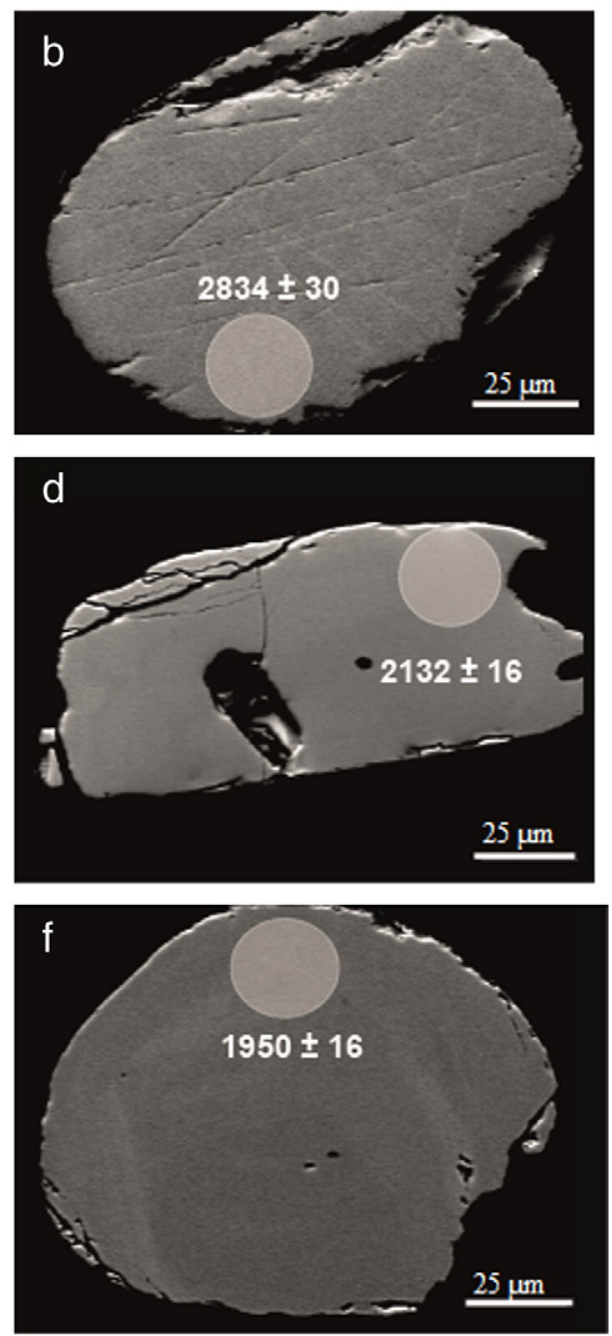

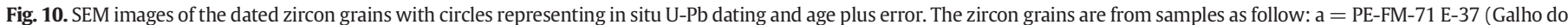

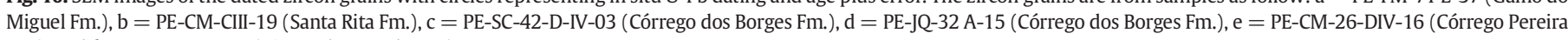
Fm.), and $\mathrm{f}=\mathrm{PE}-\mathrm{CM}-\mathrm{CIII}-19$ (Rio Pardo Grande Fm.). 

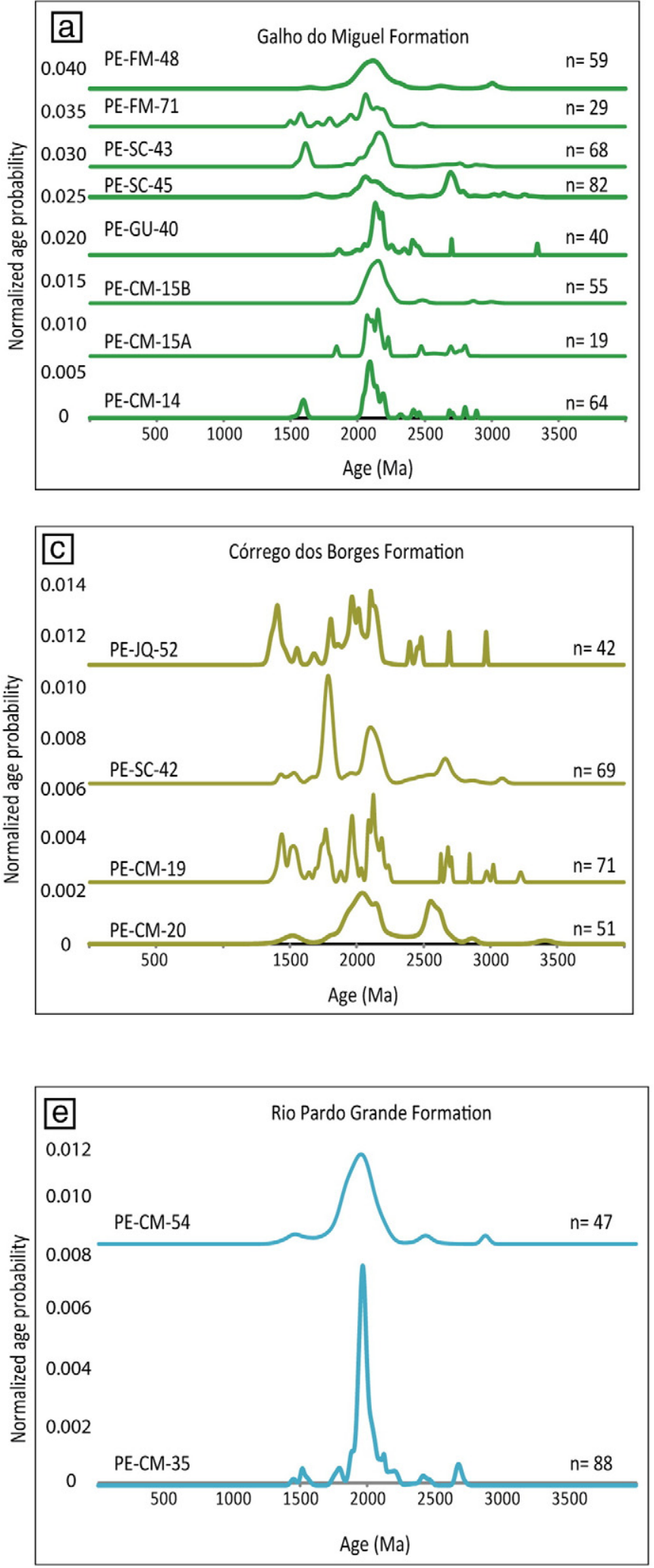
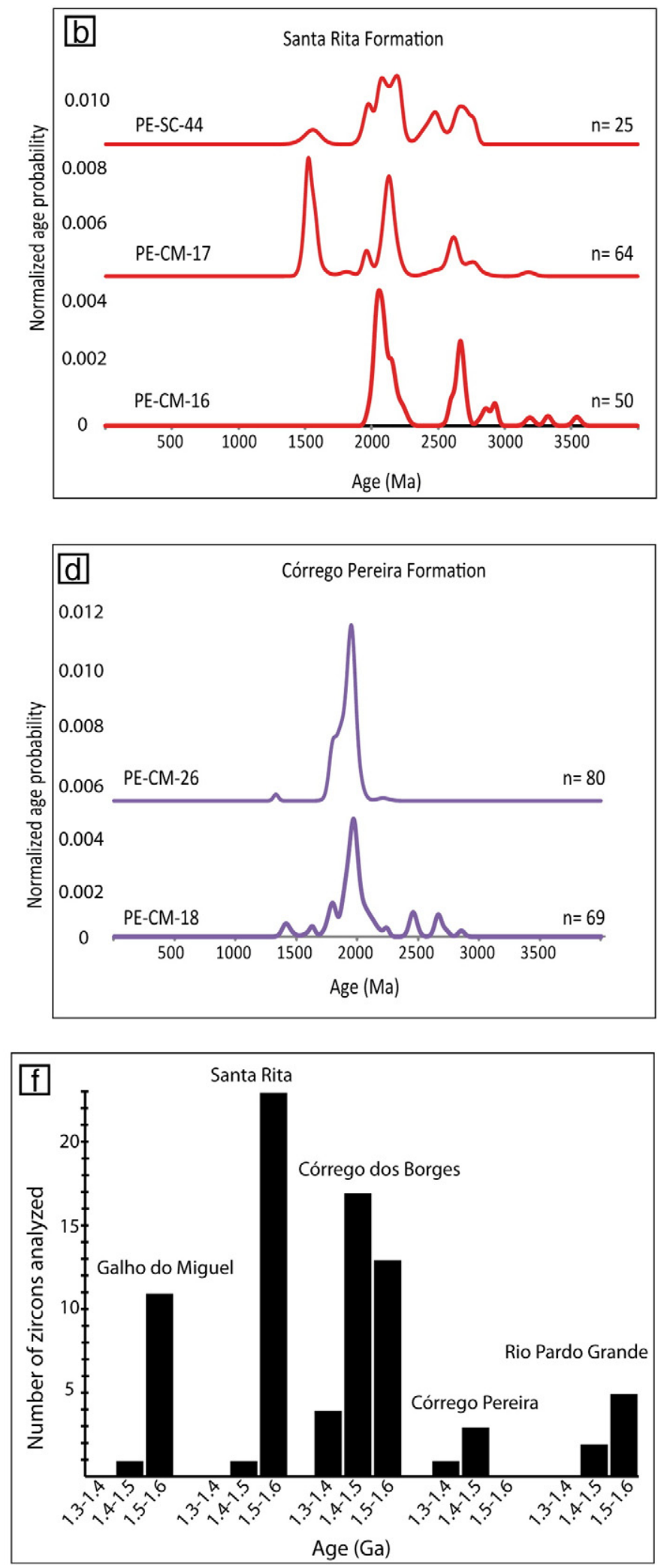

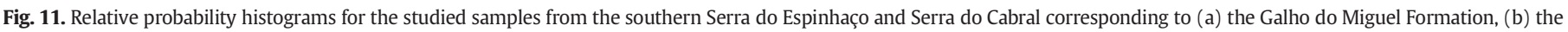

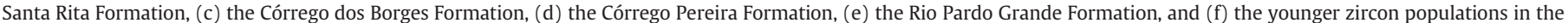
Galho do Miguel, Santa Rita, Córrego dos Borges, Córrego Pereira and Rio Pardo Grande formations. Detrital zircon data with discordance equal to or less than $10 \%$.

obtained for the Galho do Miguel Formation are approximately 1581 Ma (Fig. 11f), which were found in three sandstone samples (PE-CM-14, PESC-43 and PE-FM-71). The outcrops of these samples do not exhibit the large-scale cross-stratification that is typical of the eolian environment attributed to the formation. In these places (Fig. 1), planar-laminated to low-angle cross-stratified sandstones predominate.

Two of the three Santa Rita Formation samples have a minimum age peak of approximately $1.5 \mathrm{Ga}$ (Fig. 11b, f). This formation also features 


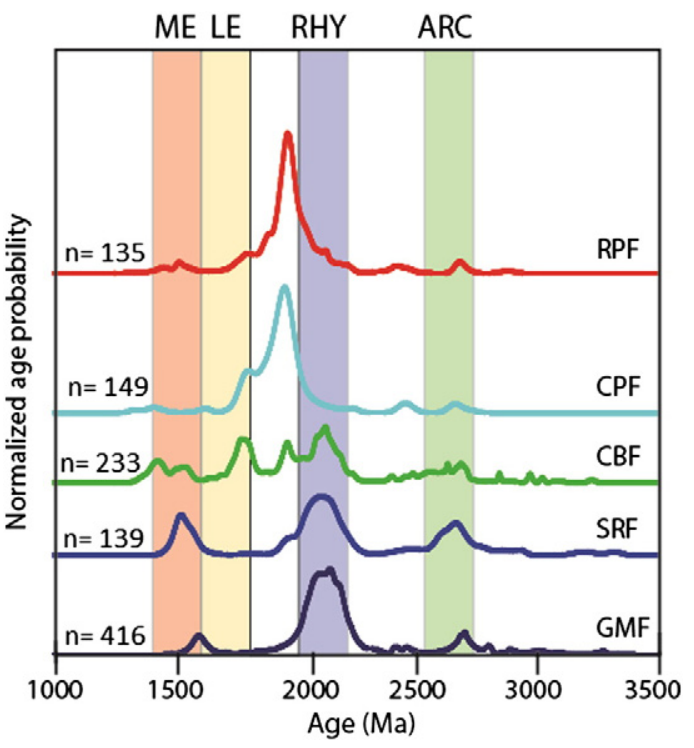

Fig. 12. Histogram with all detrital zircon ages for the main stratigraphic units of the Conselheiro Mata Group. The main domains correspond to Neoarchean (ARC), Rhiacyan (RHY), Statherian/Lower Espinhaço Sequence (LE), and Calymmian-Ectasian/Middle Espinhaço Sequence (ME). The following abbreviations are: $n=$ number of zircon grains analyzed, GMF = Galho do Miguel Fm., SRF = Santa Rita Fm., CBF = Córrego dos Borges Fm., $\mathrm{CPF}=$ Córrego Pereira Fm., and RPF = Rio Pardo Grande Fm.

main peaks at $1947 \mathrm{Ma}, 2048 \mathrm{Ma}, 2118 \mathrm{Ma}$, and $2640 \mathrm{Ma}$ and secondary peaks at $2908 \mathrm{Ma}, 3156 \mathrm{Ma}, 3298 \mathrm{Ma}$ and $3520 \mathrm{Ma}$ (Fig. 10b). There is a small discrepancy between samples PE-CM-16 (pelite from the lower portion of the Santa Rita Formation) and PE-CM-17 (sandstone from the middle portion of the Santa Rita Formation), with the former featuring a concentration of older zircons and the latter featuring younger zircons.

Of all the units studied, the samples from the Córrego dos Borges Formation possess the age spectrum with the largest variation, characterized by several age peaks within relatively short intervals of time. The youngest zircon grains have ages of between $1.3 \mathrm{Ga}$ and $1.4 \mathrm{Ga}$ (Fig. 11f). There are also main age peaks at $1777 \mathrm{Ma}, 1960 \mathrm{Ma}$, and $2183 \mathrm{Ma}$ and secondary peaks at $2540 \mathrm{Ma}, 2640 \mathrm{Ma}, 2843 \mathrm{Ma}$, $2968 \mathrm{Ma}, 3212 \mathrm{Ma}$ and $3414 \mathrm{Ma}$ (Figs. 10c, d, 11c).

The youngest zircon of the Conselheiro Mata Group (1332 $\pm 21 \mathrm{Ma}$ ) was found in sandstones from the Córrego Pereira Formation (Figs. 10e, 11f). However, most ages obtained for this formation are concentrated at approximately 1956 Ma. Zircon ages of $2434 \mathrm{Ma}, 2636 \mathrm{Ma}$ and $2812 \mathrm{Ma}$, listed in decreasing order of abundance, occur as subordinate peaks (Fig. 11d).

Five main peaks appear in the age spectra of the Rio Pardo Grande Formation: $1506 \mathrm{Ma}, 1964 \mathrm{Ma}, 2389 \mathrm{Ma}, 2667 \mathrm{Ma}$ and $2851 \mathrm{Ma}$ (Figs. 10f, 11e). However, detrital zircon ages that are approximately 2.0 Ga (Orosirian Period; Plumb, 1991) are dominant, similar to the Córrego Pereira Formation. Three samples were analyzed geochemically, including one pelite and two sandstones.

\section{Discussion}

\subsection{Provenance and geochronology}

The use of REEs and ratios such as $\mathrm{La} / \mathrm{Sc}, \mathrm{Th} / \mathrm{Sc}, \mathrm{Eu} / \mathrm{Eu}^{*}$, and LREE/ HREE for sedimentary provenance analysis assumes that these elements have low mobility during sedimentary processes, diagenesis or metamorphism (Cullers et al., 1974; Taylor and McLennan, 1985; Slack and Stevens, 1994; Cullers, 1995; Shao et al., 2001). Therefore, the abundance of these elements most likely represent the bulk composition of their source rocks (McLennan et al., 1980; Raza et al., 2010). The chondrite-normalized REE patterns of the Galho do Miguel Formation and Conselheiro Mata Group are parallel, suggesting that there were no substantial changes in the source rocks or changes in the LREE/HREE ratio caused by secondary processes.

The sedimentary rocks in the Galho do Miguel Formation and Conselheiro Mata Group feature high concentrations of REEs, patterns similar to NASC, negative Eu anomalies, high LREE/HREE ratios (Fig. 9), and high La/Sc (>2.5) and Th/Sc (>0.8) ratios. These chemical characteristics generally indicate a granitic source rock for the sediments (Schieber, 1986; Condie, 1993; Rahman and Suzuki, 2007; Raza et al., 2010).

The $\mathrm{Zr} / \mathrm{Sc}$ versus Th/Sc diagram (Fig. 8) allows us to discriminate the composition of the source rocks to the sedimentary rocks (Taylor and McLennan, 1985; McLennan, 1989; Raza et al., 2010). According to Taylor and McLennan (1985), samples with Th/Sc ratios greater than 1 reflect input from fairly evolved crustal igneous rocks, whereas $\mathrm{Th} / \mathrm{Sc}$ ratios less than 0.8 most likely reflect input from mafic sources. A $\mathrm{Zr} / \mathrm{Sc}$ ratio greater than 10 indicates a mature or recycled source. Additionally, the $\mathrm{Th} / \mathrm{U}$ ratio can be considered complementary to the $\mathrm{Zr} / \mathrm{Sc}$ ratio because $\mathrm{Th} / \mathrm{U}$ values greater than 4 may indicate sediment recycling (Rahman and Suzuki, 2007). The selective sorting of heavy minerals caused by recycling can also result in a change in the pattern of REEs (Tripathi and Rajamani, 2003), which is not the case for the rocks analyzed here. Based on these assumptions, we found that both the Galho do Miguel Formation and all the units in the Conselheiro Mata Group may contain input from felsic rocks and sedimentary rocks that have experienced only a low degree of recycling, similar to the quartzites in the Aravalli Craton, NW Indian shield (Raza et al., 2010). In most cases, the analyzed zircon grains are rounded due to sedimentary transport. Some of the zircons, and therefore the sedimentary rocks, are recycled material (Fig. 10).

Analyzing the U-Pb detrital zircon results from the Conselheiro Mata Group's units suggests a major contribution of zircon grains that formed during the Paleoproterozoic and, subordinately, the Mesoproterozoic and Archean (Fig. 12). However, note that a source of zircons generated in the Calymmian to Ectasian (Plumb, 1991) (Fig. 11f) occurs in the stratigraphic formations Galho do Miguel $(1497 \pm 17$ to $1599 \pm$ $24 \mathrm{Ma}, \mathrm{n}=12)$, Santa Rita (1489 \pm 29 to $1576 \pm 24 \mathrm{Ma}, \mathrm{n}=24)$, Córrego dos Borges ( $1361 \pm 19$ to $1583 \pm 31 \mathrm{Ma}, \mathrm{n}=34$ ), Córrego Pereira ( $1332 \pm 21$ to $1445 \pm 40 \mathrm{Ma}, \mathrm{n}=4$ ) and Rio Pardo Grande $(1400 \pm 65$ to $1547 \pm 28 \mathrm{Ma}, \mathrm{n}=7)$, which were formed in the Middle Espinhaço Sequence, as defined by Chemale et al. (2012) and Guadagnin et al. (2015). These zircon grains correspond to the younger ages found in the studied uppermost stratigraphic units of the Upper Espinhaço Sequence in the Espinhaço Basin, which were deposited between 1.18 and $0.9 \mathrm{Ga}$.

The zircon age distribution patterns of the Galho do Miguel and Santa Rita formations are very similar to those of Neoarchean, Rhyacian and Calymmian zircons (Fig. 12), suggesting that the main source areas remained constant during the sag phase in the Upper Espinhaço Sequence.

The depositional period of the Córrego dos Borges Formation indicates a slightly different pattern with the presence of Statherian zircon input and few Orosirian grains together with Rhyacian, Neo- and Paleoarchean and Calymmian zircon grains, suggesting a change in the sediment supply (Fig. 12).

During the deposition of the upper units of the Upper Espinhaço Sequence, specifically the Córrego Pereira and Rio Pardo Grande formations, there was a drastic change in the origin of the sediments, whose Orosirian sources (Fig. 12) have not yet been identified in the adjacent region. The main source areas in the surrounding areas of the Espinhaço Basin are Archean, Rhyacian, Statherian and Neoproterozoic to Early Paleozoic (e.g., Brito Neves et al., 1979; Chemale et al., 1993; Barbosa and Sabaté, 2004; Alkmim et al., 2006). There is very little contribution from the Calymnian (e.g., Silveira et al., 2013) and Stenian (Grenvillian) (e.g., Chemale et al., 2012; Chaves et al., 2013). 


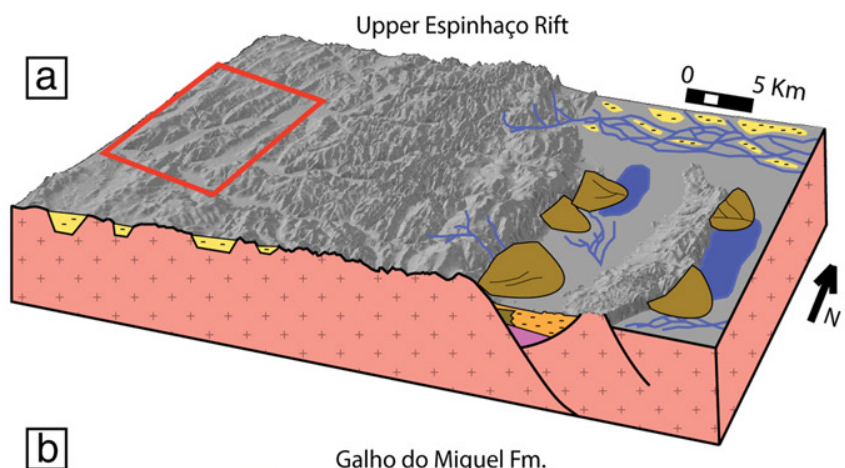

b Galho do Miguel $\mathrm{Fm}$.
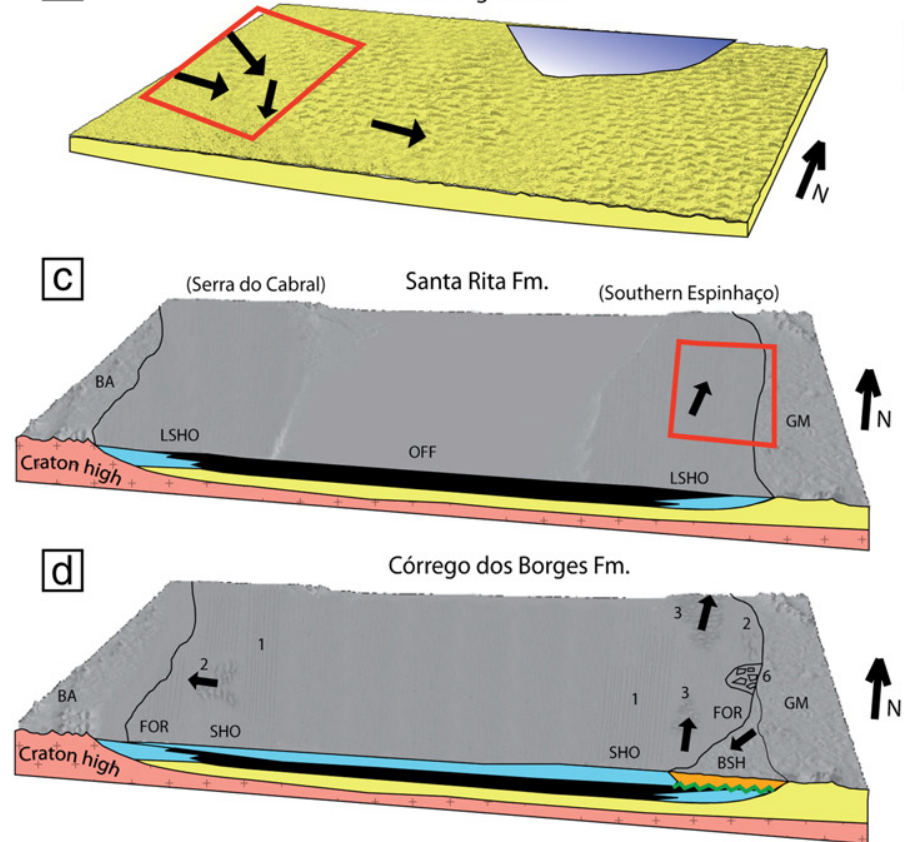
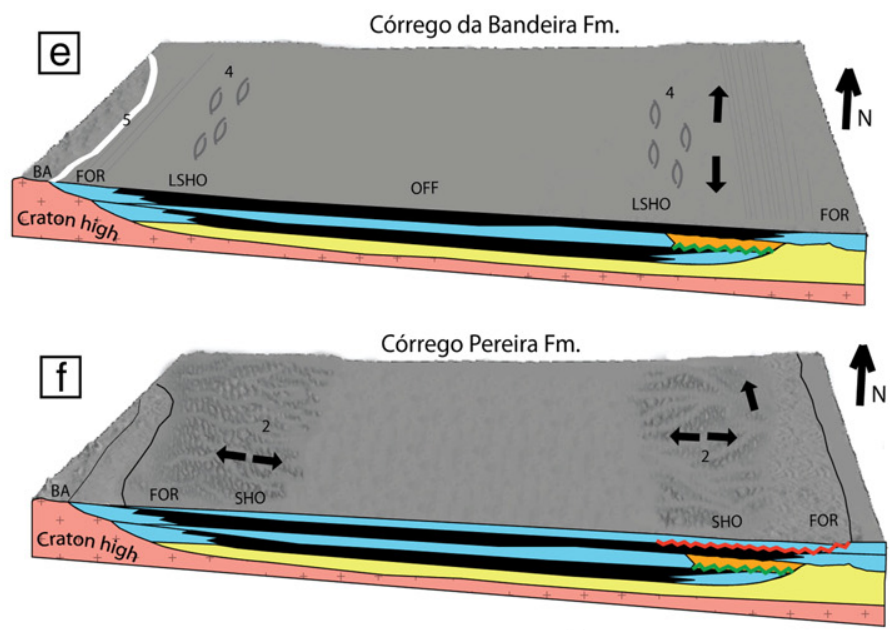

Rio Pardo Grande Fm.

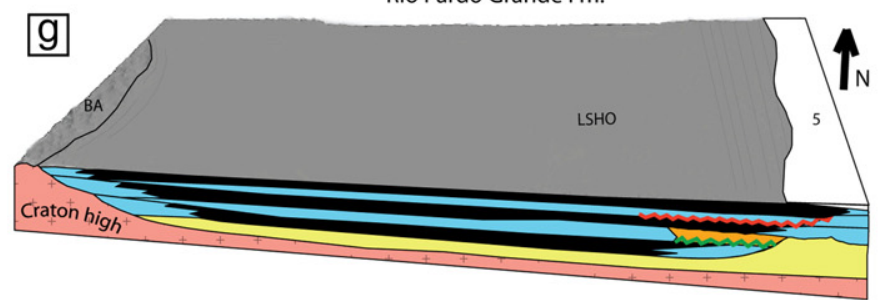

$\checkmark$ Studied area $\square$ Basement $\square$ Bandeirinha Fm. $\quad$ i São João da Chapada Fm.

- Sopa-Brumadinho Fm. $\square$ Alluvial fan deposits of Sopa-Brumadinho Fm.

Lacustrine system of Sopa-Brumadinho Fm. ㄱ Braided fluvial system of Sopa-Brumadinho Fm.

Marine system of Galho do Miguel Fm.

$\square$ Galho do Miguel Fm. $\square$ Backshore deposits
$\begin{array}{ll}\text { 1 Wave ripples } & 4 \text { Swaley and hummocky } \\ 2 \text { Tide currents } & 5 \text { Carbonate bioconstructions } \\ 3 \text { Longshore currents } & 6 \text { Breccia }\end{array}$

m Local subaerial exposure surface $\sim$ Basal surface of forced regression
OFF Offshore

FOR Foreshore BSH Backshore BA Basement Paleocurrent trends

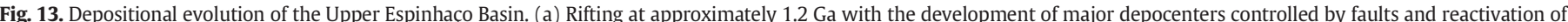

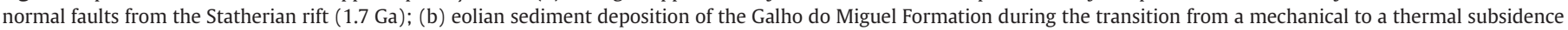

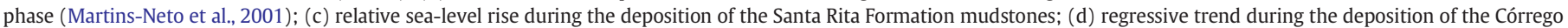

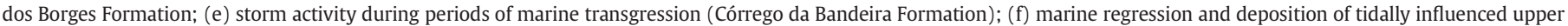
shoreface to foreshore sediments of the Córrego Pereira Formation; and (g) mudstones of the Rio Pardo Grande Formation deposited during a new marine transgression.

\subsection{Depositional systems and palaeogeography}

After the opening of the Lower Espinhaço Basin during the Statherian Period $(\sim 1.7 \mathrm{Ga})$, almost 500 Ma years elapsed before a new rifting of greater areal extent occurred at $1.2 \mathrm{Ga}$ (Stenian Period; Chemale et al., 2012) via the reactivation of preexisting normal faults and the generation of new faults located west of the western limit of the possible Statherian rift (i.e., west of the sedimentary breccias of the São João da Chapada Formation). Reis (2011) has suggested the presence of rift deposits tens of km west of Guinda, which may represent the record of the Stenian Rift (1.2 Ga; Fig. 13a).

The sedimentation in the Upper Espinhaço Basin in the southern Serra do Espinhaço began with the deposition of quartzites by braided fluvial systems and conglomerates that, in some cases, contain diamonds from deltaic and alluvial fans (Martins-Neto, 1996). Both systems belong to the Sopa-Brumadinho Formation (Martins-Neto, 2000, and references therein). During the transition from mechanical to thermal subsidence, a coastal system dominated by eolian deposits developed across a wide area of the region (Dossin et al., 1987; Martins-Neto et al., 2001; Fig. 13b). The thickness (2000-3000 m) and great areal extent of the eolian sandstones (Pflug, 1968; Schöll and Fogaça, 1979) suggest that the local paleotopography was buried. In addition, the lack of any substantial amount of coarse material in the Galho do Miguel Formation suggests low topographic relief during deposition, similar to the Jurassic eolian system in the western United States (Peterson, 1988). Marine facies at the base and top of the eolian sandstones have been described in the Guinda and Serra do Cabral regions, respectively (Espinoza, 1996; Martins-Neto, 1998). Gamma spectrometry data from an aerial survey conducted in the Guinda region (Megafísica Survey Aerolevantamentos S.A., 2001) show potassium anomalies occurring in some areas mapped as the Galho do Miguel Formation (Fogaça, 1995). These anomalies are associated with pelitic layers and fine-grained sandstones with wave ripples, low-angle cross-stratification and plane-parallel stratification. The absence of sandstones with large-scale cross-stratification; the geochemistry of the major elements, which indicates that the sandy facies have relatively high pelitic contents; and the geochronology, which indicates a distinct provenance signature that includes Calymmian detrital zircon age data $(1.5 \mathrm{Ga})$, indicate a change in depositional conditions. Further studies are needed to fully clarify such depositional systems.

The Conselheiro Mata Group is characterized mostly by marine sedimentation. Three transgressive-regressive sequences were recognized based on facies analysis and stratal stacking patterns (Fig. 4). Mudstone facies record deposition in an offshore environment at the base of the group and most likely represent the continuity of the marine transgression at the top of the Galho do Miguel Formation (i.e., a gradational transition from shoreface to offshore conditions; Fig. 13c). As seen in Figs. 2, 11b, zircon ages from the Calymmian Period (1.5 Ga) tend to 


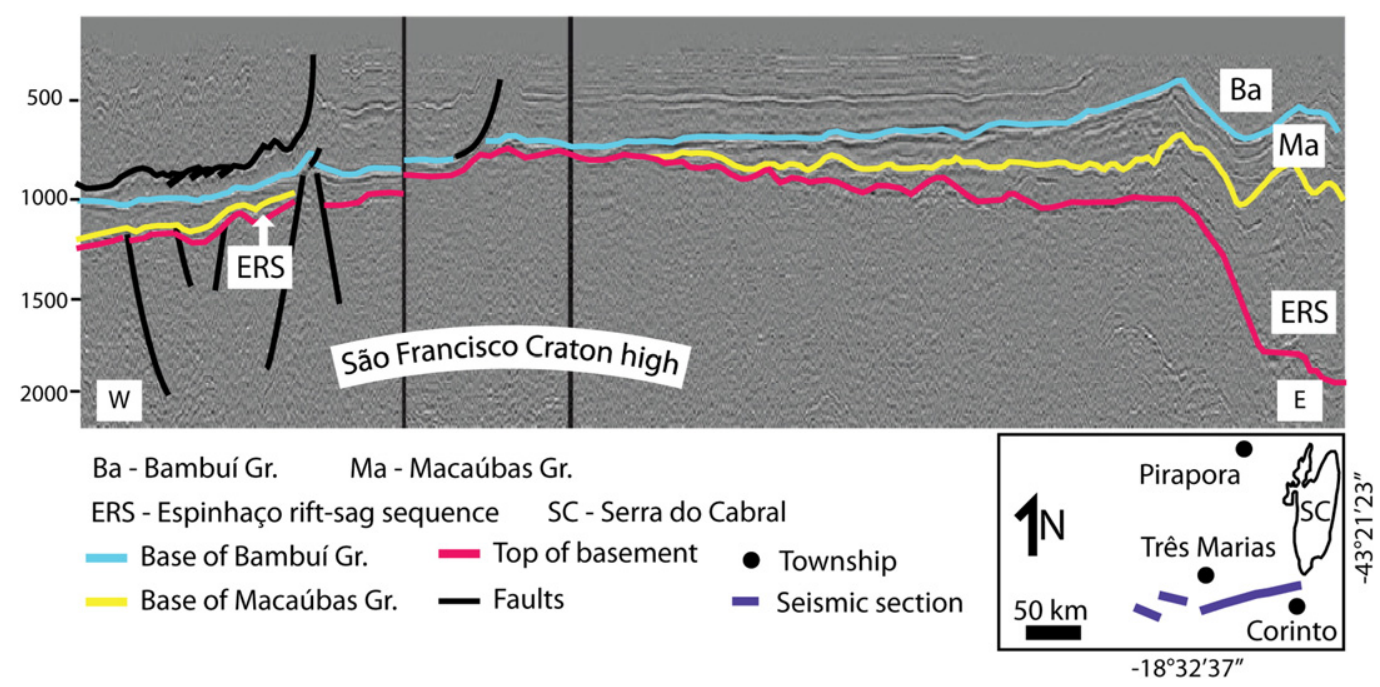

Fig. 14. Seismic reflection lines from the Espinhaço Basin (modified from Reis, 2011). Vertical scale: two-way travel time (TWT/ms).

occur in the lower shoreface deposits (middle and top of the Santa Rita Formation). The absence of zircon ages from this period in the pelitic sample PE-CM-16 most likely suggests a low terrigenous sediment supply to the offshore environment, and the subsequent regressive trend caused an increase in the sediment supply, thereby incorporating more Calymmian sediments.

The normal regression caused the development of a lower shoreface on offshore deposits and indicates that the rate of sediment supply to the coastal zone exceeded the rate of relative sea-level rise. The return of shallow marine conditions was most likely accompanied by seismic events that generated sedimentary breccias and synsedimentary deformation structures. Although the Espinhaço Supergroup was deposited in an intraplate setting, Grenvillian tectonism at the border of or within the São Francisco-Congo Craton may have influenced sedimentation (Chemale et al., 2012). Grenvillian zircon grains are scarce in the Upper Espinhaço Sequence, occurring only in the basal rift portion as thin volcaniclastic layers (Chemale et al., 2012) or volcaniclastic material on the basement structural high (Chaves et al., 2013). The sediments in the Córrego dos Borges Formation record periods of zircon generation (igneous or metamorphic) with relatively high frequencies between approximately $1.5 \mathrm{Ga}$ and $2.1 \mathrm{Ga}$ (Fig. 11c). Plane-parallelstratified and low-angle cross-bedding sandstones were deposited on the upper shoreface to foreshore, where waves and currents continually reworked the sediments. We identified two main types of marine paleocurrent directions: longshore currents toward the north and south and predominantly eastward tidal currents on the eastern shore and westward tidal currents on the western shore (Fig. 13d). The oscillatory flow in the coastal region generally shows an orientation perpendicular to the shoreline when it is dominated by waves; thus, the orientation of the wave ripple crests can be used as an approximation of the tendency of the local paleoshoreline (Leckie and Krystinik, 1989). The shallow marine deposits in the southern Serra do Espinhaço exhibits wave ripples with crests oriented north-south, as observed by Espinoza (1996) in the Serra do Cabral region, indicating a paleoshoreline with the same orientation or that the shoreline influenced the wave orientation. In stratigraphic Section 9, it is possible to

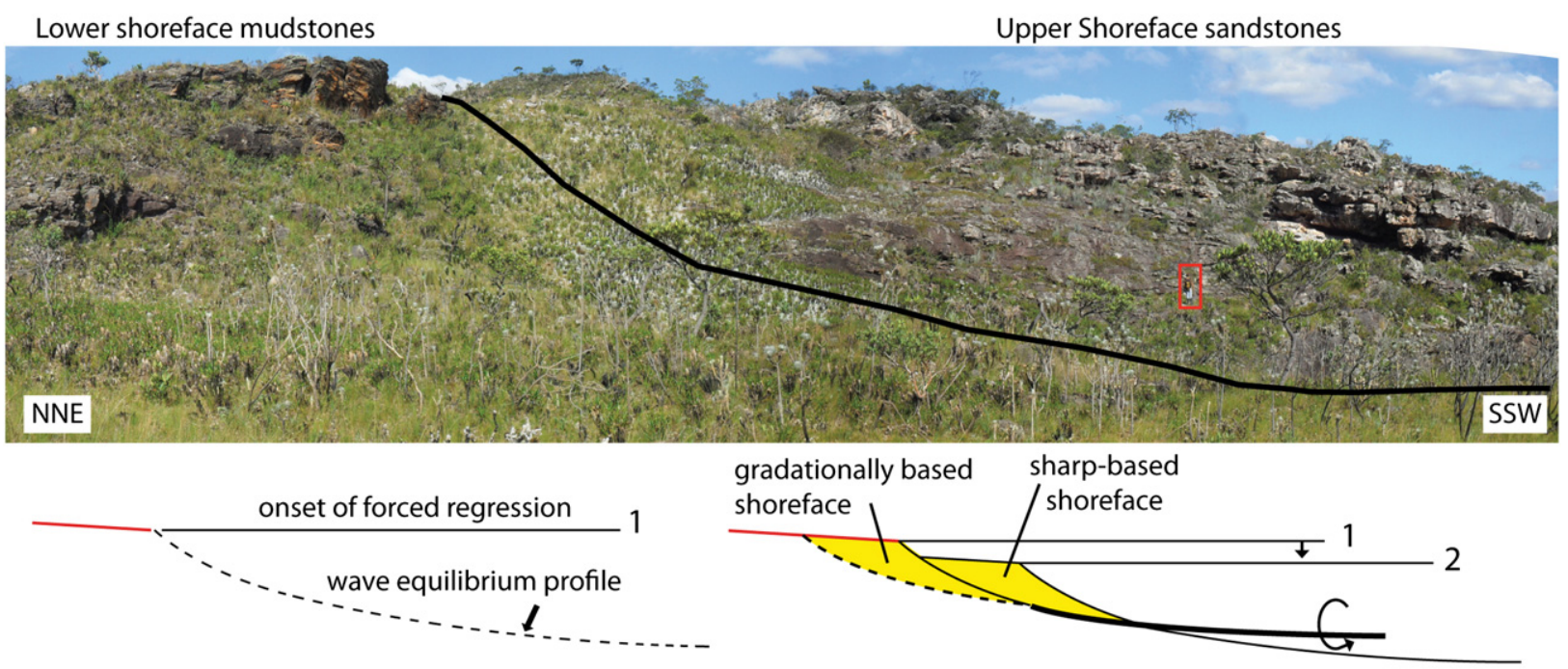

Upper shoreface _ Subaerial erosion - - - basal surface of forced regression (conformable)

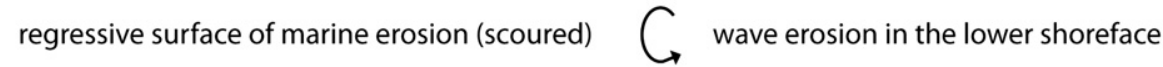

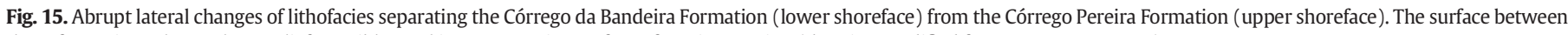
these formations shows sharp relief, possibly marking a regressive surface of marine erosion (drawing modified from Catuneanu, 2006). 
observe a coastal desert environment (dune and interdune sandstones) directly overlying offshore deposits, indicating a possible local subaerial erosion surface.

The upper shoreface (FA 2) transitions gradually into the lower shoreface (FA 5) (Fig. 13e), recording the second marine transgression. A lower shoreface condition under the action of storm waves seems to have prevailed during the deposition of the Córrego da Bandeira Formation. In the Serra do Cabral region, the reduced siliciclastic input allowed for carbonate sedimentation, although to a limited extent.

The local transition from the lower shoreface (Córrego da Bandeira Formation) to the upper shoreface (Córrego Pereira Formation) is laterally abrupt. The surface between these deposits exhibits sharp relief, possibly marking a regressive surface of marine erosion, indicating a relative sea-level fall (sensu Catuneanu et al., 2009; Fig. 15). From this pattern, we infer that the substrate on which the Conselheiro Mata Group was deposited had a low-gradient slope because it would have been more susceptible to erosion by waves than a higher-gradient shoreface during base-level fall (Catuneanu, 2006). The sedimentary structures produced during the forced marine regression indicate tidal currents toward the east and west and, secondarily, longshore currents to the north and south (Fig. 13f). The ages of the detrital zircons show that the main source is Orosirian ( 1.9-2.0 Ga) (Fig. 12). This change in sedimentary provenance may result from a change in the paleocurrent pattern and/or because of tectonic events in the source area. Of the two dated samples (Fig. 11d), sample PE-CM-18, which was collected at the base of the Córrego Pereira Formation (progradational trend; Fig. 4), contains Archean zircons, unlike sample PE-CM-26 from the top of the formation (retrogradational trend; Fig. 4). The textural characteristics of these zircons (e.g., roundness) suggest a high transport distance and/or recycling during the marine regression.

The last marine transgression of the sag phase recorded in the southern Serra do Espinhaço comprises the lower shoreface deposits of the Rio Pardo Grande Formation (Fig. 13g), which is dominated by Orosirian source rocks ( $1.97 \mathrm{Ga})$, above the upper-shoreface deposits. During the subsequent period of sea-level highstand, the rate of base-level rise decreased, resulting in a normal regression and consequent change from a predominantly siliciclastic system to a carbonate system and led to the establishment of a mixed carbonate-siliciclastic shelf (Garcia and Uhlein, 1987; Dupont, 1995). The mudstones and carbonate sediments containing stratiform stromatolites were deposited during quiet phases of sedimentation characterized by low siliciclastic influx.

The change from the dominant Rhycian source in the Córrego dos Borges to an Orosirian source in the two last units of the Conselheiro Mata Group may reflect far-field stresses along the plate margins ortectonic process in the interior of the Congo-São Francisco Paleoplate.

Seismic reflection data (Reis, 2011; Fig. 14) show the presence of a basement topographic high west of the areas studied. Fig. 14 shows that two major depocenters were separated (south of Três Marias) during the Espinhaço rift-sag phase. The basement topographic high most likely had great influence on the coastline geometry during the marine development of the Conselheiro Mata Group. The upper part of the Espinhaço sequence progressively onlap the basement, recording periods of relative rises in sea level. This stratum is bounded at the top by an erosional surface and overlain by the Macaúbas Group.

Our studies suggest that this marine sequence extended to the north and east of the Meridional Espinhaço on the São Francisco Craton and can be used for the kinematic reconstruction of supercontinent masses such as Columbia and Rondinia.

\section{Conclusions}

The Conselheiro Mata Group represents an excellent example of transgressive-regressive cycles that developed in an intracratonic sag basin during the Stenian to early Tonian (Upper Mesoproterozoic to Lower Upper Proterozoic) as part of the Upper Espinhaço Sequence (or Megasequence) of the 1.8 to $0.92 \mathrm{Ga}$ intracratonic Proterozoic Espinhaço Basin. The trace element geochemistry suggests that the provenance was mainly from granitic rocks, typical of a craton interior, and secondarily from sedimentary rocks that have experienced only a low degree of recycling, most likely from the underlying rift basin. The geochronological data indicate a provenance dominated by Paleoproterozoic and, subordinately, Paleo- to Neoarchean source terranes, coinciding with the main tectonic cycles of the basement rocks in the São Francisco Craton. Some contributions from Statherian and Calymmian sources that are part of scarce magmatism in the intracratonic Proterozoic Espinhaço Basin are also recognized.

Based on lithological and architectural element analysis, the Conselheiro Mata Group can be divided into six facies associations. FA 1 , which mostly formed from mudstones, resulted from a marine transgression and deposition in offshore to lower shoreface conditions. The main sources of these sedimentary rocks are similar to those of the underlying Galho do Miguel Formation, with ages of approximately $1.5 \mathrm{Ga}, 2.1 \mathrm{Ga}$ and $2.6 \mathrm{Ga}$. The subsequent normal marine regression was characterized by a gradual change to an upper shoreface environment (FA 2) influenced by longshore currents to the north and south, resulting in provenances from several source rocks with ages of between $1.3 \mathrm{Ga}$ and $3.4 \mathrm{Ga}$, including sediment inputs from the Lower Espinhaço Sequence. Locally, the eolian sandstones of FA 3 directly overlie offshore mudstones that record local subaerial erosion. The second transgressive-regressive cycle was marked by deposition in lower shoreface conditions under the action of storm waves followed by relative sea-level fall, represented locally by a regressive surface of marine erosion and the resumption of upper shoreface conditions. These sandstones (FA 4) were derived almost exclusively from Orosirian source rocks (peak at $1.97 \mathrm{Ga}$, whose sources have not yet been identified in the adjacent region), similar to those found in the overlying unit (FA 5 and FA 6), which marked a drastic change in the sediment supply that was likely due to changes in the paleocurrent pattern to the east and west caused by tidal influence and/or may reflect tectonic processes in the source area. A new transgression-regression cycle records a change from a predominantly siliciclastic system (pelites in FA 5) to a carbonate system (dolostones in FA 6) and led to the establishment of a mixed carbonate-siliciclastic shelf.

Supplementary data to this article can be found online at http://dx. doi.org/10.1016/j.sedgeo.2014.12.006.

\section{Acknowledgements}

We would like to thank the CAPES, CNPq (grant no. 304045/2010-1) and PETROBRAS for their financial support for the field work and analysis. We also thank Giorgio Basilici, an anonymous reviewer and the Editor Jasper Knight, for improving the quality of the manuscript.

\section{References}

Alkmim, F.F., 2004. O que faz de um cráton um cráton? O cráton do São Francisco e as revelações almeidianas ao delimitá-lo. In: Mantesso-Neto, V., Bartorelli, A., Carneiro, C.D.R., Neves, B.B. (Eds.), Geologia do Continente Sul-Americano, Evolução da Obra de Fernando Flávio Marques de Almeida. Beca, São Paulo, pp. 17-35.

Alkmim, F.F., Martins-Neto, M.A., 2012. Proterozoic first-order sedimentary sequences of the São Francisco craton, eastern Brazil. Mar. Pet. Geol. 33, 127-139.

Alkmim, F.F., Marshak, S., Pedrosa-Soares, A.C., Peres, G.G., Cruz, S., Whittington, A., 2006. Kinematic evolution of the Araçaí-West Congo orogen in Brazil and Africa: nutcracker tectonics during the Neoproterozoic assembly of Gondwana. Precambrian Res. 149, 43-64.

Allen, P.A., Armitage, J.J., 2012. Cratonic basins. In: Busby, C., Perez, A.A. (Eds.), Tectonics of sedimentary basins: recent advances. Wiley-Blackwell, Oxford, pp. 602-620.

Almeida-Abreu, P.A., 1993. A Evolução Geodinâmica da Serra do Espinhaço Meridional, Minas Gerais, Brasil. (Ph. D. Thesis), Univ. Freiburg, Freiburg, Germany (150 pp.).

Anthony, E.J., Orford, J.D., 2002. Between wave- and tide-dominated coasts: the middle ground revisited. J. Coast. Res. Spec. Issue 36, 8-15. 
Barbosa, J.S.F., Sabaté, P., 2004. Archean and Paleoproterozoic crust of the São Francisco Craton, Bahia, Brazil: geodynamic features. Precambrian Res. 133, 1-27.

Batista, A.J., Castro, W.B.M., Greco, F.M., 1986. Geologia da Serra do Espinhaço entre Conselheiro Mata e Rodeador, Minas Gerais. XXXIV Congresso Brasileiro de Geologia, Goiânia, Anais 2, pp. 949-959.

Bergner, A.G.N., Strecker, M.R., Trauth, M.H., Deino, A., Gasse, F., Blisniuk, P., Dühnforth, M., 2009. Tectonic and climatic control on evolution of rift lakes in the Central Kenya Rift, East Africa. Quat. Sci. Rev. 28, 2804-2816.

Bosence, D.W.J., 1998. Stratigraphic and sedimentological models of ritf basins. In: Purser, B.H., Bosence, D.W.J. (Eds.), Sedimentation and tectonics of rift basins: Red Sea - gulf of Aden. Chapman and Hall, London, pp. 9-25.

Brito Neves, B.B., Cordani, U.G., Kawashita, K., Delhal, J., 1979. A evolução geocronológica da Cordilheira do Espinhaço; dados novos e integração. Rev. Bras. Geosci. 9, 71-85.

Brito Neves, B.B., de SÁ, J.M., Nilson, A.A., Botelho, N.F., 1995. A Tafrogênese Estateriana nos blocos paleoproterozóicos da América do Sul e processos subsequentes. Geonomos 3, 1-21.

Catuneanu, O., 2006. Principles of sequence stratigraphy. Elsevier, Amsterdam (375 pp.).

Catuneanu, O., Abreu, V., Bhattacharya, J.P., Blum, M.D., Dalrymple, R.W., Eriksson, P.G., Fielding, C.R., Fisher, W.L., Galloway, W.E., Gibling, M.R., Giles, K.A., Holbrook, J.M., Jordan, R., Kendall, C.G.St.C., Macurda, B., Martinsen, O.J., Miall, A.D., Neal, J.E., Nummedal, D., Pomar, L., Posamentier, H.W., Pratt, B.R., Sarg, J.F., Shanley, K.W., Steel, R.J., Strasser, A., Tucker, M.E., Winker, C., 2009. Towards the standardization of sequence stratigraphy. Earth Sci. Rev. 92, 1-33.

Chaves, M.L.S., Silva, M.C.R., Scholz, R., Babinski, M., 2013. Grenvillian age magmatism in the Southern Espinhaço Range (Minas Gerais): evidence from U-Pb zircon ages. Braz. J. Geol. 43, 477-486.

Chemale Jr., F., Alkmim, F.F., Endo, I., 1993. Late Proterozoic Tectonism in the interior of the São Francisco Craton. In: Findlay, R.H., Banks, H.R., Veevers, J.J., Unrug, R. (Eds.), Gondwana 8: assembly, evolution and dispersal. Balkema, Rotterdam, pp. 29-41.

Chemale Jr., F., Dussin, I.A., Martins, M.S., Alkmim, F.F., Queiroga, G., 2010. The Espinhaço Supergroup in Minas Gerais: a Stenian Basin? 7th South American Symposium on Isotope Geology, Brasília, pp. 552-555

Chemale Jr., F., Philipp, R.P., Dussin, I.A., Formoso, M.L.L., Kawashita, K., Bertotti, A.L., 2011. Lu-Hf and U-Pb age determinations of Capivarita Anorthosite in the Dom Feliciano Belt, Brazil. Precambrian Res. 186, 117-126.

Chemale Jr., F., Dussin, I.A., Alkmim, F.F., Martins, M.S., Queiroga, G., Armstrong, R., Santos, M.N., 2012. Unravelling a proterozoic basin history through detrital zircon geochronology: The case of the Espinhaço Supergroup, Minas Gerais, Brazil. Gondwana Res. 22, 200-206.

Clifton, H.E., 2006. A re-examination of facies models for clastic shorelines. In: Posamentier, H.W., Walker, R.G. (Eds.), Facies models revisited. SEPM, Special Publication 84, pp. 293-337.

Condie, K.C., 1993. Chemical composition and evolution of the upper continental crust: Contrasting results from surface samples and shales. Chem. Geol. 104, 1-37.

Cook, R., Warren, A., Goudie, A., 1993. Desert geomorphology. UCL Press, London (526 pp.).

Cullers, R.L., 1995. The controls of the major- and trace-element evolution of shales, siltstones and sandstones of Ordovician to Tertiary age in the Wet Mountains region, Colorado, USA. Chem. Geol. 123, 107-131.

Cullers, R.L., Yeh, L.-T., Chaudhuri, S., Guidotti, C.V., 1974. Rare earth elements in Silurian pelitic schists from N.W. Maine. Geochim. Cosmochim. Acta 38, 389-400.

Davis Jr., R.A., Hayes, M.O., 1984. What is a wave dominated coast? Mar. Geol. 60, 313-329.

DeCelles, P.G., Cavazza, W., 1992. Constraints on the formation of Pliocene hummocky cross-stratification in Calabria (southern Italy) from consideration of hydraulic and dispersive equivalence, grain-flow theory, and suspended-load fallout rate. J. Sediment. Petrol. 62, 555-568.

Dossin, I.A., Uhlein, A., Dossin, T.M., 1984. Geologia da Faixa Móvel Espinhaço em sua porção meridional, MG. Congresso Brasileiro de Geologia, 33, Rio de Janeiro: Anais, Sociedade Brasileira de Geologia 2, pp. 3118-3132.

Dossin, I.A., Garcia, A.J.V., Uhlein, A., Dardenne, M.A., Dossin, T.M., 1987. Fácies eólico na Formação Galho do Miguel. Supergrupo Espinhaço (MG). Simpósio sobre Sistemas Deposicionais no Pre-Cambriano, Ouro Preto: Atas, Sociedade Brasileira de Geologia, pp. 85-96.

Dossin, I.A., Dossin, T.M., Chaves, M.L.S.C., 1990. Compartimentação Estratigráfica do Supergrupo Espinhaço em Minas Gerais - os Grupos Diamantina e Conselheiro Mata. Rev. Bras. Geosci. 20, 178-186.

Dossin, I.A., Dossin, T.M., Charvet, J., Cocherie, A., Rossi, P., 1993. Single-zircon dating by step-wise $\mathrm{Pb}$-evaporation of Middle Proterozoic magmatismo in the Espinhaço range, southeastern São Francisco Craton. Minas Gerais, Brazil. Simpósio sobre o Cráton do São Francisco, 2, Salvador, 1993: Anais, Sociedade Brasileira de Geologia/ Superintendência de Geologia e Recursos Minerais da Bahia 1, pp. 39-42.

Dott, R.H., Bourgeois, J., 1982. Hummocky crossstratification: Significance of its variable bedding sequence. Geol. Soc. Am. Bull. 93, 663-680.

Droxler, A.W., Schlager, W., 1985. Glacial versus interglacial sedimentation rates and turbidite frequency in the Bahamas. Geology 13, 799-802.

Duke, W.L., Arnott, R.W.C., Cheel, R.J., 1991. Shelf sandstones and hummocky crossstratification: New insights on a stormy debate. Geology 19, 625-628.

Dumas, S., Arnott, R.W.C., 2006. Origin of hummocky and swaley cross-stratification - The controlling influence of unidirectional current strength and aggradation rate. Geology 34, 1073-1076.

Dupont, H., 1995. O Grupo Conselheiro Mata no seu quadro paleogeográfico e estratigráfico. Simpósio de Geologia de Minas Gerais, Diamantina: Anais, Sociedade Brasileira de Geologia 13, pp. 9-10.

Dussin, I.A., 1994. Evolution Structurale de la pertie méridional de L'Espinhaço sur la bordure orientale du Craton São Francisco. Minas Gerais - Brésil: Um exemple de tectonique protérozoique superposé. Universite d'Orleans, Orleans (Ph. D. Thesis, 200 pp.).
Dussin, I.A., Dussin, T.M., 1995. Supergrupo Espinhaço: Modelo de evolução geodinâmica Geonomos 3, 19-26.

Espinoza, J.A.A., 1996. Sistemas deposicionais e relações estratigráficas da Tectonosseqüência Conselheiro Mata, na borda leste da Serra do Cabral, Minas Gerais, Brasil. (MSc Thesis), Departamento de Geologia, Escola de Minas, Universidade Federal de Ouro Preto, Ouro Preto (66 pp.).

Fernandes, L.A., Castro, A.B., Basilici, G., 2007. Seismites in continental sand sea deposits of the Late Cretaceous Caiuá Desert, Bauru Basin, Brazil. Sediment. Geol. 199, 51-64.

Fogaça, A.C.C., 1995. Geologia da Folha Diamantina. Projeto Espinhaço. COMIG-UFMG Belo Horizonte (98 pp.).

Fraga, L.M.S., Neves, S.C., Uhlein, A., Sial, A.N., Pimentel, M.M., Horn, A.H., 2014. C-, Sr-isotope stratigraphy of carbonate rocks from the Southern Espinhaço Ridge Minas Gerais, southeastern Brazil. An. Acad. Bras. Cienc. 86, 633-648.

Fryberger, S.G., Schenk, C.J., 1988. Pin stripe lamination: A distinctive feature of modern and ancient eolian sediments. Sediment. Geol. 55, 1-15.

Galloway, W.E., Hobday, D.K., 1996. Terrigenous clastic depositional systems; applications to fossil fuel and groundwater resources. Second edition. Springer, New York (489 pp.).

Garcia, A.J.V., Uhlein, A., 1987. Sistemas deposicionais do Supergrupo Espinhaço na Região de Diamantina (MG). Simpósio sobre Sistemas Deposicionais no Pre-Cambriano, Ouro Preto, Atas, Sociedade Brasileira de Geologia, pp. 113-136.

Gawthorpe, R.L., Leeder, M.R., 2000. Tectono-sedimentary evolution of active extensional basins. Basin Res. 12, 195-218.

Gromet, L.P., Dymek, R.F., Haskin, L.A., Korotev, R.L., 1984. The "North American shale composite"; Its compilation, major and trace element characteristics. Geochim. Cosmochim. Acta 48, 2469-2482.

Guadagnin, F., Chemale Jr., F., Magalhães, A.J., Santana, A., Dussin, I., Takehara, L., 2015 Age constraints on crystal-tuff from the Espinhaço Supergroup - Insight into the Paleoproterozoic to Mesoproterozoic intracratonic basin cycles of the São Francisco Craton. Gondwana Res. 27, 363-376.

Haskin, L.A., Wildeman, T.R., Haskin, M.A., 1968. An accurate procedure for the determination of the rare earths by neutron activation. J. Radioanal. Chem. 1, 337-348.

Inman, D.L., Ewing, G.C., Corliss, J.B., 1966. Coastal sand dunes of Guerrero Negro, Baja California, Mexico. Geol. Soc. Am. Bull. 77, 787-802.

Jackson, S.E., Pearson, N.J., Griffin, W.L., Belousova, E.A., 2004. The application of laser ablation-inductively coupled plasma-mass spectrometry to in situ U-Pb zircon geochronology. Chem. Geol. 211, 47-69.

Knight, J., 2008. The environmental significance of ventifacts: A critical review. Earth Sci. Rev. 86, 89-105.

Krapez, B., 1996. Sequence stratigraphic concepts applied to the identification of basinfilling rhythms in Precambrian successions. Aust. J. Earth Sci. 43, 355-380.

Kreisa, R.D., Moiola, R.J., 1986. Sigmoidal tidal bundles and other tide-generated sedimentary structures of the Curtis Formation, Utah. Geol. Soc. Am. Bull. 97, 381-387.

Laity, J.E., 1994. Landforms of aeolian erosion. In: Abrahams, A., Parsons, A. (Eds.) Geomorphology of desert environments. Chapman and Hall, London, pp. 506-535.

Leckie, D.A., Krystinik, L.F., 1989. Is there evidence for geostrophic currents preserved in the sedimentary record of inner to middle shelf deposits? J. Sediment. Petrol. 59, 862-870.

Lindsay, J.F., 2002. Supersequences, superbasins, supercontinents - evidence from the Neoproterozoic-Early Palaeozoic basins of central Australia. Basin Res. 14, 207-223.

Livingstone, I., Warren, A., 1996. Aeolian geomorphology: An introduction. Addison-Wesley, Singapore (211 pp.).

Lopes, T.C., 2012. O Supergrupo Espinhaço na Serra do Cabral, Minas Gerais: contribuição ao estudo de proveniência sedimentar. (MSc Thesis). Instituto de Geociências, Universidade Federal de Minas Gerais, Belo Horizonte, Brazil (110 pp.).

Ludwig, K.R., 2003. Using Isoplot/Ex, version 3.00, a geochronological toolkit for Microsoft Excel. Berkeley Geochronology CenterSpecial Publication 1 (43 pp.).

Machado, N., Schrank, A., Abreu, F.R., Knauer, L.G., Almeida-Abreu, P.A., 1989. Resultados preliminares da geocronologia U/Pb na Serra do Espinhaço Meridional. Boletim da Sociedade Brasileira de Geologia, Núcleo Minas Gerais 10 pp. 171-174.

Marshak, S., Alkmim, F.F., 1989. Proterozoic contraction/extension tectonics of the Southern São Francisco Region, Minas Gerais, Brazil. Tectonics 8, 555-571.

Martins-Neto, M.A., 1996. Lacustrine fan-deltaic sedimentation in a Proterozoic rift basin: the Sopa-Brumadinho Tectonosequence, southeastern Brazil. Sediment. Geol. 106, 65-96.

Martins-Neto, M.A., 1998. O Supergrupo Espinhaço em Minas Gerais: Registro de uma Bacia Rifte-Sag do Paleo/Mesoproterozóico. Rev. Bras. Geol. 48, 151-168.

Martins-Neto, M.A., 2000. Tectonics and sedimentation in a paleo/mesoproterozoic rift-sag basin (Espinhaço basin, southeastern Brazil). Precambrian Res. 103, 147-173.

Martins-Neto, M.A., Pedrosa-Soares, A.C., Lima, S.A.A., 2001. Tectono-sedimentary evolution of sedimentary basins from Late Paleoproterozoic to Late Neoproterozoic in the São Francisco craton and Araçuá fold belt, eastern Brazil. Sediment. Geol. 141-142, 343-370.

McLennan, S.M., 1989. Rare earth elements in sedimentary rocks: influence of provenance and sedimentary processes. In: Lipin, B.R., McKay, G.A. (Eds.), Geochemistry and mineralogy of rare earth elements. Reviews in Mineralogy 21, pp. 169-200.

McLennan, S.M., Nance, W.B., Taylor, S.R., 1980. Rare earth element - thorium correlations in sedimentary rocks, and the composition of the continental crust. Geochim. Cosmochim. Acta 44, 1833-1839.

Megafísica Survey Aerolevantamentos S.A., 2001. Relatório final do levantamento e processamento dos dados magnetométricos e gamaespectrométricos. Levantamento Aerogeofísico de Minas Gerais, Área 4 faixa São João Chapada - Datas. Volume I. Texto técnico.

Mountney, N.P., 2006. Eolian facies models. In: Posamentier, H.W., Walker, R.G. (Eds.), Facies models revisited. Society for Sedimentary Geology, Special Publication 84 pp. 19-83. 
Nio, S.D., Yang, C., 1991. Diagnostic attributes of clastic tidal deposits: a review. In: Smith D.G., Reinson, G.E., Zaitlin, B.A., Rahmani, R.A. (Eds.), Clastic Tidal Sedimentology: Canadian Society of Petroleum Geologists. Memoir 16, pp. 3-28.

Peterson, F., 1988. Pennsylvanian to Jurassic eolian transportation systems in the western United States. Sediment. Geol. 56, 207-260.

Pflug, R., 1968. Observações sobre a estratigrafia da Série Minas na região de Diamantina, Minas Gerais. Boletim da Divisão de Geologia e Mineralogia do Departamento Nacional de Produção Mineral: Notas Preliminares 142 (20 pp.).

Plumb, K.A., 1991. New Precambrian time scale. Episodes 14, 139-140.

Prosser, S., 1993. Rift-related linked depositional systems and their seismic expression. In: Williams, G.D., Dobb, A. (Eds.), Tectonics and seismic sequence stratigraphy. Geological Society, London, Special Publications 71, pp. 35-66.

Rahman, M.J.J., Suzuki, S., 2007. Geochemistry of sandstones from the Miocene Surma Group, Bengal Basin, Bangladesh: Implications for Provenance, tectonic setting and weathering. Geochem. J. 41, 415-428.

Raza, M., Bhardwaj, V.R., Ahmad, A.H.M., Mondal, M.E.A., Khan, A., Khan, M.S., 2010. Provenance and weathering history of Archaean Naharmagra quartzite of Aravalli craton, NW Indian Shield: Petrographic and geochemical evidence. Geochem. J. 44, 331-345.

Reineck, H.E., Singh, I.B., 1980. Depositional sedimentary environments. Springer-Verlag, Berlin, Heidelberg, New York (551 pp.).

Reis, H.LS., 2011. Estratigrafia e tectônica da Bacia do São Francisco na zona de emanações de gás natural do baixo Rio Indaiá (MG). (MSc Thesis), Universidade Federal de Ouro Preto, Ouro Preto, Brazil (127 pp.).

Santos, M.N., Chemale Jr., F., Dussin, I.A., Martins, M.S., Assis, T.A.R., Jelinek, A.R Guadagnin, F., Armstrong, R., 2013. Sedimentological and paleoenvironmenta constraints of the Statherian and Stenian Espinhaço Rift System, Brazil. Sediment. Geol. 290, 47-59.

Schieber, J., 1986. Stratigraphic control of rare-earth pattern types in Mid-Proterozoic sediments of the Belt Supergroup, Montana, U.S.A.: Implications for basin analysis. Chem. Geol. 54, 135-148.

Schöll, W.U., 1980. Estratigrafia, sedimentologia e paleogeografia na região de Diamantin (Serra do Espinhaço, Minas Gerais, Brasil). Münstersche Forschungen zur Geologie und Paläontologie 51 pp. 223-240.

Schöll, W.U., Fogaça, A.C.C., 1979. Estratigrafia da Serra do Espinhaço na região de Diamantina. Simpósio de Geologia de Minas Gerais, Diamantina: Anais, Sociedade Brasileira de Geologia, pp. 55-73.
Shao, L., Stettegger, K., Garbe-Schoenberg, C.D., 2001. Sandstone petrology and geochemistry of the Turpan basin (NW China): implications for the tectonic evolution of a continental basin. J. Sediment. Res. 71, 37-49.

Silveira, E.M., Söderlund, U., Oliveira, E.P., Ernst, R.E., Menezes Leal, A.B., 2013. First precise U-Pb baddeleyite ages of 1500 Ma mafic dykes from the São Francisco Craton, Brazil, and tectonic implications. Lithos 174, 144-156.

Slack, J.F., Stevens, B.P.J., 1994. Clastic metasediments of the early proterozoic broken-hill group, New-south-Wales, Australia - geochemistry, provenance, and metallogenic significance. Geochim. Cosmochim. Acta 58, 3633-3652.

Sloss, L.L., 1963. Sequences in the Cratonic Interior of North America. Geol. Soc. Am. Bull. $74,93-114$.

Southard, J.B., Lambie, J.M., Federico, D.C., Pile, H.T., Wideman, C.R., 1990. Experiments on bed configurations in fine sand under bidirectional purely oscillatory flow, and origin of hummocky cross stratification. J. Sediment. Petrol. 60, 1-17.

Souza Filho, R.C. 1995. Arcabouço estrutural da porção externa da Faixa Araçuaí na Serra do Cabral (MG) e o contraste de estilos deformacionais entre os Supergrupos Espinhaço e São Francisco. (MSc Thesis), Universidade Federal de Ouro Preto, Ouro Preto, Brazil (148 pp.).

Swift, D.J.P., Figueiredo, A.G., Freeland, F.L., Oertel, G.F., 1983. Hummocky cross-stratification and megaripples: a geological double standard? J. Sediment. Petrol. 53, 1295-1318.

Tape, C.H., Cowan, C.A., Runkel, A.C., 2003. Tidal-bundle sequences in the Jordan Sandstone (Upper Cambrian), southeastern Minnesota, USA: Evidence for tides along inboard shorelines of the sauk epicontinental sea. J. Sediment. Res. 73, 354-366.

Tate, M.P., 1993. Structural framework and tectono-stratigraphic evolution of the Porcupine Seabight Basin, offshore western Ireland. Mar. Pet. Geol. 10, 95-123.

Taylor, S.R., McLennan, S.M., 1985. The continental crust: Its composition and evolution. Blackwell, Oxford (312 pp.).

Tripathi, K.J., Rajamani, V., 2003. Geochemistry of Proterozoic Delhi quartzite: Implications for the provenance and source area weathering. J. Geol. Soc. India 62, 215-226.

Uhlein, A., Trompette, R., Egydio-Silva, M., 1998. Proterozoic rifting and closure, SE border of the São Francisco Craton, Brazil. J. Afr. Earth Sci. 11, 191-203.

Walker, R.G., 1984. Shelf and shallow marine sands. In: Walker, R.G. (Ed.), Facies models, Second edition. Geological Association of Canada, Geoscience Canada Reprint Series 1, pp. 141-170. 